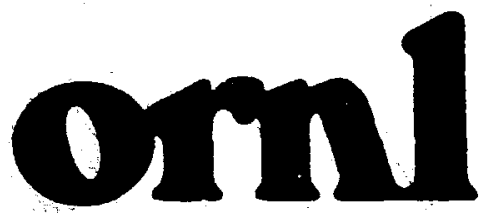

MASTER

OAK

RIDGE

NATIONAL

ABORATORY .

Union

CARBIDE

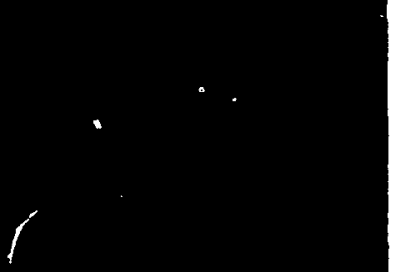

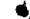

\section{An Assessment of Radiation Doses from Residential Smoke Detectors that Contain Americium-241}
F. R. O'Donnell
E. L. Etnier
G. A. Holton
C. C. Travis

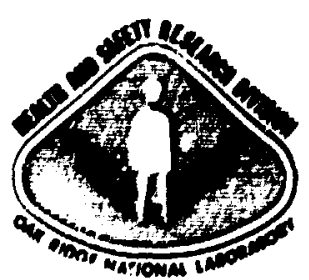


ORHL -5807

Dist. Category UC-41

Contract No. W-7405-eng-26

HEALTH ANO SAFETY RESEARCH OIVISION

AN ASSESSHENT OF RADIATION DOSES FRON RESIDENTIAL SMOKE DETECTORS THAT CONTAIN AMERICIUM-241
F. R. D'Donn' -?1
E. L. Etnier
G. A. Holton
C. C. Travis

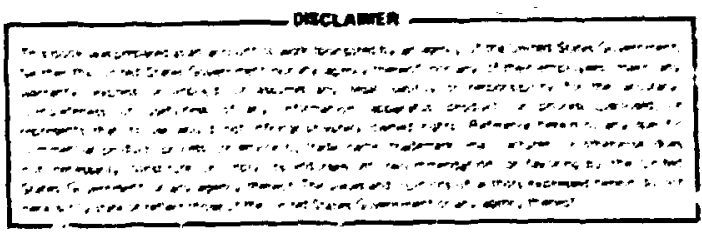

Date Published - October 1981

OAK RIDGE NATIONAL LABORATORY

Oak Ridge, Tennessee $3783 \mathrm{C}$ operated by UNICN CARBIDE CORPORATION

for the

DEPARTMENT OF ENERGY 
LIST OF FIGURES ...................... . . iv

LIST OF TABLES. .......................

ABSTRACT. .............................. vi

SUMARY .................................. ix

1. INTRODUCTION. ..................... 1

2. PRODUCT INFORMATION ............................. 2

3. ASSESSHENT STRATEGY ................. 6

4. DOSE ESTIMATES. .................. 11

4.1 Transport of Smoke Detectors ............. 11

4.2 Distribution of Smoke Detectors. . . . . . . ... 16

4.3 Use of Snoke netectors ................ 20

4.4 Disposal of Smoke Detectors. . . . . . . . . . 23

4.4.1 Waste collection. . . . . . . . . . . 24

4.4.2 Land disposal ............... 24

4.4.3 Incineration. ............. 30

4.5 Fires. . . . . . . . . . . . . . 32

4.5.1 Residential fires............ 32

4.5.2 Warehouse fires............. 34

4.5.3 Cleanup after fire. . . . . . . . . 34

4.6 Ingestion of Source Foils. . . . . . . . . 35

REFERENCES ....................... 37

APPENDIX A. Detailed Tabulations of Exposure Conditions. . . . 41

APPENDIX B, Detailed Tabulations of Radiation Doses. . . . . . 51 


\section{LIST OF FIGURES}

Figure

Page

1 General view ci the transport ad distribution of smoke detectors from suppitit to destination.....

2 Flow chart for the transport of 5 million snoke detectors from the supplier to a chain siore warehouse.

3 Flow chart for the transport of 5 million smoke detectors from the supplier to a wholesale warehouse ... 15

4 Flow chart for the distribution of smoke detectors from a chain store warehouse to a large chain store . 18

5 Flow chart for the distribution of smoke detectors from a wholesale warehouse to small retail stores 


\section{LIST OF TABLES}

Table

Page

1 Sumary of potential radiation doses to individuals and the population from distribution, use, disposal and. unusual events involving 10 million ionization chamber snoke detectors.

2 Sumary of annual total-body radiation doses from various sources in the United States........... xi

3 Relationships between sove SI units and previously used units ..................... 3

4 Values of prefix symbols used in this report ........ 3

5 Domestic distribution of $241 \mathrm{Am}$ in smoke detectors. . . . 4

6 Data for 241 An (radioactive half-life $=4.33 E 02 \mathrm{Y}$ )... 9

7 Sumary of total-body doses due to transport of smoke detectors................... 17

8 Sumary of total-body doses due to distribution of smoke detectors................. 21

9 Exposure conditions and radiation doses from use of two swoke detectors each containing $110 \mathrm{kBa}$ of $231 \mathrm{~km} . . .22$

10 Exposure conditions and external radiation doses to municipal solid waste collectors from disposal of 10 million snoke detectors containing $110 \mathrm{kBq}$ of $241 \mathrm{Am}$ each.......................

11 Radiation doses to individuals and populations from land disposa? of 10 mil!ion 241 Am-containing smoke detectors. ................ 28

12 Population dose estinates for airborne release of $140 \mathrm{kBq}$ of $24 \cdot \mathrm{Am}$ from an incinerator stack (1 willion persons).

12 Time-dependent fraction of 8-iour dose comitment received by individuals during fire. . . . . . . . . . 


\section{ABSTRACT}

External dose equivalents and internal dose comitments were estiated for individuals and populations from annual distribution, use, and disposal of 10 million ionization chamber swoke detectors that contain $110 \mathrm{kBq}(3 \mu \mathrm{Ci})$ americium-241 each. Under exposure scenarios developed for normal distribution, use, and disposal using the best available information, annual external dose equivalents to average individuals were estinated to range from $4 \mathrm{fSv}(0.4 \mathrm{prem})$ to $20 \mathrm{nSv}$ (2 $\mu$ rea) for total body and from $7 \mathrm{fSv}$ to $40 \mathrm{nSv}$ for bone. Internal dose comitments to individuals under post disposal scenarios were estimated to range from 0.006 to $80 \mu \mathrm{Sv}(0.0006$ to $8 \mathrm{mrem})$ to total body and from 0.06 to $800 \mu S v$ to bone.

The total collective dose (the sum of external dose equivalents and 50-year internal dose comitments) for all individuals involved with distribution, use, or disposal of 10 million smoke detectors was estimated to be about 0.38 person-Sv ( 38 person-rem) to tota? body and 1.3 bone-Sv (130 bone-rem). 


\section{SUMARY}

Ionization chamber swoke detectors contain swall awounts, typically $110 \mathrm{kBq}(3 \mu \mathrm{C} i)$, of the radioactive material, $241 \mathrm{An}$. Therefore, they are potential sourcas of radiation exposure to the general public. This report presents estimates of external radiation dose equivalents and internal 50-year cose comitments that might be received by individuals and the population of the United States from annual distribution, use, and disposal of 10 million ionization chamber swoke detectors. Although considerable uncertainty exists in these estimates, they indicate typical and naximum radiological impacts of smoke detectors on various populatior g:oups (distribution workers, store custoners, residential users, etc.).

Persons who wight be exposed to the smoke detectors were divided into functionally related groups. An exposure scenario was constructed for a representative individual from each group. The scenarios were then used to calculate doses (external dose equivalents or internal 50-year dose comitments) to the group members. Irdividual doses were sumped to obtain population doses.

Exposure scenarios were constructed from information on acmestic smoke detector use obtained from the litcrature and U. S. Nuclear Regulatory Commission's licensing files. These scenarios represented groups of persons involved in transport, distribution, use, and disposal of smoke detectors. In addition, consideration was given to persons who could be exposed to the radiation from smoke detectors incidentally and accidentilly during transport, distributio.1, disposal, and unusual circumstances.

Table 1 is a summary of potential external dose equivalents and internal dose commitments to total tody and bone (the critical organ) of ine individuals and population groups considered in this assessment. Under normal conditions, average external dose equivalents tn individ-

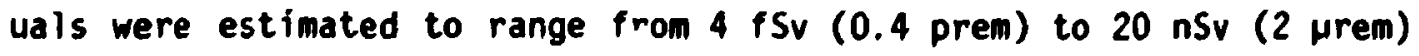
to totai body, and from $7 \mathrm{fSv}$ tn $40 \mathrm{nSv}$ to bone. Highest total-body dose equivalents ( $80 \mathrm{nSv}$ ) were calculated for 14 local delivery truck drivers. These same individuals could receive dose equivalents of 160 
Table 1. Summary of potential radiation doses to individuals and the population from distribution, use, disposal, and unusual events involving $10 \mathrm{~m} f 11$ ton

ionization, chamber smoke detect.ors

\begin{tabular}{|c|c|c|c|c|c|c|}
\hline & \multirow{2}{*}{$\begin{array}{l}\text { Number } \\
\text { of } \\
\text { persons }\end{array}$} & \multicolumn{3}{|c|}{ To total body } & \multicolumn{2}{|c|}{ To bone } \\
\hline & & $\begin{array}{c}\text { Individual, } \\
\text { Average }\end{array}$ & Sv & $\begin{array}{c}\text { Collective, } \\
\text { person-Sv }\end{array}$ & $\begin{array}{c}\text { Individual, Sv } \\
\text { Average }\end{array}$ & $\begin{array}{c}\text { Collective, } \\
\text { bone-sv }\end{array}$ \\
\hline \multicolumn{7}{|l|}{ Normal events: } \\
\hline $\begin{array}{l}\text { Transport workers } \\
\text { Distribution workers } \\
\text { Store customers } \\
\text { Persons on truck }\end{array}$ & $\begin{array}{l}5 E+3^{a} \\
7 E+5 \\
2 E+8\end{array}$ & $\begin{array}{l}1 E-8 \\
2 E-8 \\
5 E-10\end{array}$ & & $\begin{array}{l}5 E-5 \\
2 E-2 \\
1 E-1\end{array}$ & $\begin{array}{l}2 E-8 \\
3 E-8 \\
1 E-9\end{array}$ & $\begin{array}{l}1 E-4 \\
2 E-2 \\
2 E-1\end{array}$ \\
\hline routes & $2 E+8$ & $7 E-15$ & & $2 E-6$ & $1 E-14$ & $3 E-6$ \\
\hline \multicolumn{7}{|l|}{ Residential users: } \\
\hline $\begin{array}{l}\text { Howeowner } \\
\text { Mate } \\
\text { Others }\end{array}$ & $\begin{array}{l}5 E+6 \\
5 E-6 \\
5 E+6\end{array}$ & $\begin{array}{l}1 E-8 \\
2 E-8 \\
9 E-9\end{array}$ & & $\begin{array}{l}6 E-2 \\
1 E-1 \\
5 E-2\end{array}$ & $\begin{array}{l}2 E-8 \\
4 E-8 \\
2 E-8\end{array}$ & $\begin{array}{l}1 E-1 \\
2 E-1 \\
9 E-2\end{array}$ \\
\hline Waste collection & $2 E+5$ & $1 E-9$ & & $2 E-4$ & $2 E-9$ & $4 E-4$ \\
\hline $\begin{array}{l}\text { Persons near incin- } \\
\text { erators }\end{array}$ & $2 E+8$ & $6 E-12^{b}$ & & $9 E-4^{b}$ & $7 E-11^{b}$ & $1 E-2^{b}$ \\
\hline \multicolumn{7}{|l|}{ Unusual events: } \\
\hline $\begin{array}{l}\text { Drinking contaminated } \\
\text { water }\end{array}$ & $5 E+5$ & $1 E-7^{b}$ & & $6 E-2^{b}$ & $2 E-6^{b}$ & $7 E-1^{b}$ \\
\hline \multicolumn{7}{|l|}{ Eating crops: } \\
\hline $\begin{array}{l}\text { Irrigated with con- } \\
\text { taminated water } \\
\text { Grokn near landfill } \\
\text { Grown on landfill }\end{array}$ & $\begin{array}{l}2 E+8 \\
2 E+8 \\
2 E+7\end{array}$ & $\begin{array}{l}9 E-12^{b} \\
2 E-10^{b} \\
3 E-10^{b}\end{array}$ & $=$ & $\begin{array}{l}2 E-3^{b} \\
5 E-2^{b} \\
i E-3^{h}\end{array}$ & $\begin{array}{l}1 E-1 p^{b} \\
3 E-9 b \\
3 E-g^{b}\end{array}$ & $\begin{array}{l}2 E-2^{b} \\
6 E-1 b \\
7 E-2^{b}\end{array}$ \\
\hline
\end{tabular}


Table 1. (continued)

\begin{tabular}{|c|c|c|c|c|c|}
\hline & \multirow{2}{*}{$\begin{array}{c}\text { Number } \\
\text { of } \\
\text { persons }\end{array}$} & \multicolumn{2}{|c|}{ To total body } & \multicolumn{2}{|c|}{ To bone } \\
\hline & & $\begin{array}{c}\text { Individual, Si } \\
\text { Average }\end{array}$ & $\begin{array}{l}\text { Collective, } \\
\text { person-Sv }\end{array}$ & $\begin{array}{c}\text { Individi!n 1, Sv } \\
\text { Average! }\end{array}$ & $\begin{array}{c}\text { Collective, } \\
\text { bone-sv }\end{array}$ \\
\hline Warehouse fire & $c$ & $8 E-5^{b}$ & $c$ & $8 E-4^{b}$ & 0 \\
\hline Home fire & $7 E \div 3$ & $3 E-7^{b}$ & $2 E-3^{b}$ & $3 E-6^{b}$ & $2 E-2^{b}$ \\
\hline Cleanup after fire & $c$ & $6 E-g^{b}$ & $\dot{v}$ & $6 E-8^{b}$ & 0 \\
\hline Foil ingestion & 0 & $5 E-4^{b}$ & $c$ & $6 E-3^{b}$ & $c$ \\
\hline
\end{tabular}

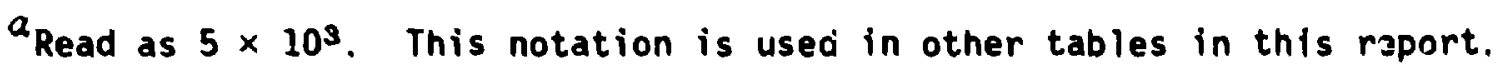

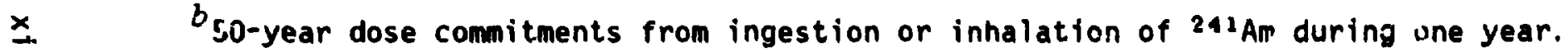

CNot estimated. 
nSv to bone. Resijential users of sarke detectors were estinated to roceive slightly lower dose equivalents: 9 to $50 \mathrm{nSv}(0.9$ to $5 \mu \mathrm{rem})$ to total body, and from 20 to $100 \mathrm{nSv}(2$ to $10 \mu \mathrm{rem}$ ) to bone.

Internal dose comitments to individuals under post disposal and unusual scenarios (excluding foil ingestion) were estimated to range from 6 pSv to $80 \mu \mathrm{Sv}$ (0.6 nrea tu $8 \mu \mathrm{rem})$ to total body and from $70 \mathrm{pSv}$ to $800 \mu \mathrm{Sv}(7$ nrem to $80 \mathrm{mrem})$ to bone. The highes:- individual internal dose comitments in this group were for firefighters at warehouse fires.

Total annual collective doses (the sum of external dose equivalents and 50-year internal dose comitments) for all individuals involved with distribution, use, or disposal of 10 million swoke detectors was estimated to be about. 0.38 persor:-5v ( 38 person-rem) to total body and 1.3 bone-Sv (130 bonf-rem).

When compared with typical annual radiation doses from other sources of exposure (Table 2), the doses potentially associated with transport, distribution, use, and disposal of ICSDs are quite low. The estimated annual collective dose associated with 10 allion ICSDs appears to be six orders of magnitude lower than that from natural radiation. Individual doses from nomal exfosures to ICSDS range from 4 to 12 orders of magnitude lower than doses from the other sources. 
Table 2. Sumary of annual total-body radiation doses from various sources: in the United States

\begin{tabular}{|c|c|c|}
\hline Source & $\begin{array}{l}\text { Average individual } \\
\text { dose equivalents (Sv) }\end{array}$ & $\begin{array}{l}\text { Porulatinn dose } \\
\text { equivalents } \\
\text { (person-Sv) }\end{array}$ \\
\hline \multicolumn{3}{|l|}{ Environmental } \\
\hline $\begin{array}{l}\text { Natural } \\
\text { Global fallout } \\
\text { Nuclear power }\end{array}$ & $\begin{array}{l}1.0 E-3 \\
4.0 E-5 \\
3.0 E-8 \\
\end{array}$ & $\begin{array}{l}2.1 E+5 \\
8.2 E+3 \\
7.0 \\
\end{array}$ \\
\hline Subtotal & 1. $1 E-3$ & 2. $2 E+5$ \\
\hline \multicolumn{3}{|l|}{ Medical } \\
\hline $\begin{array}{l}\text { Diagnostic } \\
\text { Radiopharmaceuti- } 7 \text { is }\end{array}$ & $\begin{array}{l}7.2 \mathrm{E}-4 \\
1.0 \mathrm{E}-5 \\
\end{array}$ & $\begin{array}{l}1.5 E+5 \\
2.0 E+3 \\
\end{array}$ \\
\hline Subtotal & $7.3 E-4$ & $\therefore .5 E+5$ \\
\hline Occupational & 8. OE-6 & $1.6 E+3$ \\
\hline Miscellaneous & $2.0 \mathrm{E}-5$ & $5.0[+3$ \\
\hline Total & $1.8 \mathrm{E}-3$ & 3. $7 E+5$ \\
\hline ICSDs (normal events) & $\begin{array}{l}\text { 4. } 0 E-15 \text { to } \\
\text { 7. CE-8 }\end{array}$ & $3.8 E 1$ \\
\hline
\end{tabular}

Source: National Academy of Scienres, Natioral Research Council, The Effects on Population of Exposure to Low Levels of Ionizing Radiation, Report of the Advisory Comnittee on the Biological Effects of Ionizing Radiations, Washington, D.C. 20006 (November 1972). 


\section{INTRODUCTION}

Residential fires rank as the second wost frequent cause of accidental death in the home in the $U$. S. Early detection of home fires can be a key element in reducing this toll on life and the associated property losses. Since 1969, over 25 million ionization chaber swoke deteciors (ICSDs) have been distributed in the United States. Alnost all of these ICSDs contained small amounts of the radicactive material anericium-241 (241Am), thus making ICSDs potential sources of exposure to the general public from ionizing radiation.

Because 241Am is classified as a "byproduct waterial," its use is regula'.ed by the U. S. Nuclear Regulatory Comission (NRC). Current (1980) regulations require that manufacture and import of ICSOs be licensed, but place no restrictions on their receipt, possession, use, transfer, and acquisition (i.e., these actions are exempt from regulation and requirements for a license) (Code of Federal Regulations, 1980).

This report was prepared with funds supplied by the NRC under Interagency Agreement No. DOE 40-543-75. Support was provided by the Office of Engineering Standards, Division of Engineering Standards, which was transferred during April 1981 to the Offic'. of Nuclear Regulatory Research, Division of Risk Analysis. This report contains estimates of radiation dose equivalents that might be received by the population of the United States during unrestricted transport, distribution, use, and disposal of 10 million ICSDs that contain $110 \mathrm{kBq}$ ( $3 \mu \mathrm{C} i$ ) of $241 \mathrm{Am}$ each. It complements, adds to, and supports other published smoke detector studies (Wrenn and Cohen, 1979; Belanger, Buckley, and Swenson, 1979).

Information concerning manufacture, transport, and distribution of ICSDs was obtained from the NRC's licensing files. This information and that gleaned from available literature was used to construct representative scenarios (sets of exposure conditions) for transport, distribution, use, and disposal of smoke detectors. The resultant sets of conditions were the bases for calculating radiution doses to exposed persons. 
Section 2 of this repcrt contains a description of ICSDs and an explanation of their operation. Section 3 contains a discussion of the strategy and methods used to estimate radiation .oses to man. Section 4 contains estimates of radiation dose equivalents to persons from exposures that may occur during transport, distribution, 1se, and disposal of (including fires and unusual events). Each of thr:se sections contains specifications of the exposure conditions used to make the dose estimates. This done in recognition of the fact that we selected for use in this assessment a small, representative (neither worst nor best) sample of the infinitely large number of possible scenarios.

In compliance with the official policy of the Oak Ridge National Labolatory, this report uses tive International Sysiem of Units (SI). The relationship between the new SI units and the previously used units for the radiation quartities found in this report are given in Table 3. For convenience, the numerical values of prefix symbols used in this report are given in T3ble 4.

\section{PRODUCT INFORMATION}

Information obtained from the $N R$ indicates that approximacely 25 million ICSOs were disiriblted throughout the United States isetween 1969 and 1978 (Table 5). These detect.ors are designed to protect life or property by sounding an alarm when airborne products of combuscion from a fire reach a predetermined concentration. The relative merits of available smoke detector types (ICSDs and others) are not of concern in this report. They have been discussed amply elsewhere (Belanger, Buckley, and Swenson, 1979; Organization for Economic Cooperation and Development, 1977; USNRC, 1978; Wrenn and Cohen, 1979; and the many references cited in these reports). These studies find that the various detect,or types complement each other, and are all beneficial under certain conditions. (Most fire prevention experts recommend installation of both an ICSD and a photoelectric detector in the home.)

An ICSD consists essentially of an ionization chamber, electronic circuitry, an $A C$ power supply or battery, an alarm, and an outer case. 
Table 3. Relationships betweer, some SI units and previously used units

\begin{tabular}{|c|c|c|c|}
\hline Quant: $: j$ & $\begin{array}{c}\text { SI unit } \\
\text { and symbol }\end{array}$ & $\begin{array}{l}\text { Previ.uus unit } \\
\text { and symbol }\end{array}$ & Conversicn factor \\
\hline Activity & becquerel, $\mathrm{Bq}$ & curie, $\mathrm{Ci}$ & $1 \mathrm{~Bq}=2.7 \mathrm{E}-11 \mathrm{Ci}$ \\
\hline Dose equivalent & sievert, Sv & ren & $1 \mathrm{~Sv}=100 \mathrm{rem}$ \\
\hline Energy & joule, J & electron volt, ev & $1 \mathrm{~J}=6.2 \mathrm{E}+18 \mathrm{eV}$ \\
\hline
\end{tabular}

Table 4. Values of prefix symbols used in this report

\begin{tabular}{cccc}
\hline Prefix & Vilue & Prefix & Value \\
\hline a & $10^{-18}$ & $m$ & $10^{-3}$ \\
$f$ & $10^{-15}$ & $k$ & $10^{3}$ \\
p & $10^{-12}$ & $M$ & $10^{6}$ \\
n & $10^{-9}$ & $G$ & $10^{9}$ \\
$\mu$ & $10^{-6}$ & $T$ & $10^{12}$ \\
\hline
\end{tabular}


Table 5. Domescic distribution of $241 \mathrm{Am}$ in smoke detectors ${ }^{a}$

\begin{tabular}{|c|c|c|c|c|c|}
\hline \multirow{2}{*}{ Year } & \multirow{2}{*}{$\begin{array}{l}\text { Number } \\
\text { of units } \\
\text { distributed }\end{array}$} & \multirow{2}{*}{$\begin{array}{c}\text { Total } 241 \text { Am activity } \\
\text { distributed } \\
\text { (i. } 3 q)\end{array}$} & \multicolumn{2}{|c|}{$\begin{array}{c}241 \mathrm{Am} \text { activity per unit } \\
(\mathrm{MBg})\end{array}$} & \multirow{2}{*}{$\begin{array}{c}\text { Number } \\
\text { of } \\
\text { distributors }\end{array}$} \\
\hline & & & Average & Range & \\
\hline 1969 & 30 & 0.037 & 1.2 & $b$ & 1 \\
\hline 1970 & 59,000 & 174 & 2.9 & $b$ & 1 \\
\hline 1971 & 65,000 & 191 & 2.9 & $0 . c .37-2.9$ & 3 \\
\hline 1972 & 121,000 & 310 & 2.6 & $0.037-2.9$ & 3 \\
\hline 1973 & 254,000 & 411 & 1.6 & $0.030-2.5$ & 4 \\
\hline 1974 & 390,000 & 340 & 0.87 & $0.015-1.7$ & 7 \\
\hline 1975 & 703,000 & 399 & 0.57 & $0.012-1.3$ & 30 \\
\hline 1976 & $3,352,000$ & 801 & 0.24 & $0.011-0.7$ & 14 \\
\hline 1977 & $7,928,000$ & 1590 & 0.20 & $0.015-1.9$ & 17 \\
\hline $1978^{\circ}$ & $14,200,000$ & 1690 & 0.12 & $0.0074-1.1$ & 34 \\
\hline
\end{tabular}

${ }^{a}$ Derived f onl data supplied by the U. S. Nuclear Regulatory Commission.

${ }^{b}$ Values unavailable.

CBelanger et al. , 1979. 
The ionization chabber is the central compnent. It contains a source of ionizing radiation (241Aa) posi ined between two oppositely charged electrodes. Alpha particles emitted during radioactive decay of the 241 Am interact with neutral air wolecules flowing through the chamber and ionize them positively by ejecting an electron. The ejected electrons form negative ions by attachment to neutra! air molecules. The resulting ions are attracted toward the oppositely charged electrode, thus establishing a small, reasonably steady electric current between the electrodes. The electronic circuitry monitors this current and, when the current changes by nore thail a predetermined anoun:, triggers the alarm.

Under normal conditions, ior, production and removal are in equilibrium. However, if the air ente, ing the ionization chaber contains particles (viz., combustion products) that are much more massive than the air molecules, this equilibrium will be disturbed. The nore massive particles capture some of the ions and electrons in the chasber. Because they are more massive, the resulting charged particles move toward the electrodes more slowly than do the ions. This allows some of the particle-ion pairs to be sw-pt out of the chamber by the airflow before reaching the appropriate electrode. The net effect is a reduction in the ionization chazber current. When the current drops below a predetermined leval, the alarm will sound.

Some ICr.Ds contain two ionization chambers. One chamber acts as a reference, the other as $\approx$ measurement chamber. The reference chamber is constructed to prevent entry of combustion products and, thus, monitors only ambient air. The measurement chamber acts as the single unit described above. In this design, the electronic circuitry senses differences between the current flows in the two chambers. If the current in the measurement chamber drops below that in the reference chanber by a preostermined amount, the alarm will sound.

Tabie 5 is a summary of 241 Am-containing ICSD distribution in the United States. Since becoming generally available during 1969, the number of ICSOs distributed each year has increased rapidly, and surpassed $14 \mathrm{~m}^{\circ} 11$ ion in 1978. The average $241 \mathrm{Am}$ contents cf the detectors has decreased from $2.9 \mathrm{MBq}(79 \mu \mathrm{Ci})$ in 1970 to $0.12 \mathrm{MBq}(3.2 \mu \mathrm{Ci})$ in 
1978. Manufacturers' project that the numerical distribution will level off below the 1978 value, and that the average $241 \mathrm{Am}$ content of ICSDs will cübtinue to decrease (Belanger, Buckley, and Swenson, 1979). The $\mathrm{m}$ aber of licensed distributors has also increased significantly since 1975.

The sources of ionizing radiation used in ICSOs coisist of .1- to 3-m wide strips or 5-m dianeter dises that are cut or punched from a 0.2-w thick composite. The composite consists of a 0.002-m-thick mixture of gold and $241 \mathrm{Am}$ that is hot-forged onto a 0.2-nm-thick silver

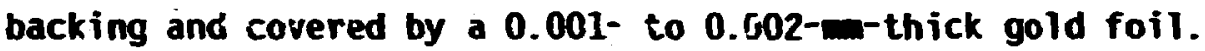

We did not assess, at our sponsor's (the NRC's) request, manufacture of ICSDs or the anericilm-containing foils. (See U. J. Nuclear Regulatory Comission, 1978, for an assessment.) Finished ICSDs are packaged and distributed as ordinary constwer products. Wrapped in a plastic bag, each detector is boxed singly, three boxes to a carcon. Host 5mol.e detectors are purchased from retail stores and installeJ in homes. All snoke detectors are mounted manually on ceilings or walls usually orie or two per home in halls or bedrooms. Once installed, the smoke detectors should be maintair.ed by replacing batteries (for those which require battciies), testing the alarm, and cleaning air intakes. Manufacturers estimace that properly maintained smoke detectors should have a useful life of ten years. At the end of their useful life, most detectors are discarded as domestic solid waste, and may be replaced with new detectors.

\section{ASSESSMENT STRATEGY}

The purpose of this study was tu provide a basis for estimating potential radiation dose equivalents to individuals and the pcpulation of the United States from ICSDs. To do this, average dise equivalents (hereafter simply called doses) to total body, bone (skeleton), and, in some cases, lungs were calculated witı the aid of the CONDOS methodology and computer code (0'Donnell et al., 1981) for aiiviul transport, distribution, use, and disposal of 10 million ICSOs that contain $3 \mu C i$ 
of $241 \mathrm{~A}$ each. As prescribed by the rethodology, the population was divided into functionaliv related groups of persons. Each group was rapresented by a typical individual who was assumed to be exposed to ICSDs under a set of exposure events described in Sect. 4 and Appendix $A$. The computer code and the exposure conditions were used to: (1) calculate external dose equivalents and internai duse cumitments to incividuai group members; (2) sum individual doses to give group pnpulation doses; and (3) sum group doses to give overall population doses.

Population groups considered include: (1; truck drivers, truckterminal workers, and persons along truck routes who could be-exposed during transport of ICSDE fram 7 suppliers to 70 large retail store warehouses and 700 wholesale-distribution warehouses; (2) warchouse workers, truck drivers, retail stock and sales clerks, store customers, and persons along truck routes who coulc be exposed during handling of ICSDs $i_{i}$ the warehouses, transport from the warehouses to 21,000 large chain stores and 210,000 small retaii stores, and handling and sale in the retail store:s: (3) persons who could be exposed during use of ICSDs in residences; (4) persons who could be exposed iuring and after disposal of broken ICSDs; and (5) persons exposed during a residential or warehousc fire. Section 4 contains descriptions of each group considered and listings of tha exposure conditions assumed for each group.

External doses are the result of exposures to photuns emitted during radioactive decay of the ${ }^{241} \mathrm{Am}$ contained in sources (viz., ICSDs and air) external to the bodies of exposed individuals. External dose equivalents given in this report are the sums of doses received during one year of such exposures. Internal dose commitnents are the result cf exposures to all radiations (photons, alpha, beta particles) emitted by nuclides taken into the bodies of exposed persons via inhalation and ingestion. Internal doses given in this report are 50-ysar dose commitments, that is, the sums of doses received over the succeeding 50 years from radionuclides inhaled and ingested during the year considered.

All doses were calrulated using the CONDOS II computer code (0'Donnell et a1., 1981). CONDOS calculates external doses fron direct 
exposures to physical objects (e.g., ICSOs) and imersion in contaminated air, and internal doses from inhalation and ingestion of radionuclides released from ICSDs. In all cases, the dose calculations are based on appropriate input data.

COMDS solves standard source geonetry equations to calculate doses from physical objects. Dose-rate conversion factors (Kocher, 1980) are used to ca?culate doses from immersion in contamineted air. All organ doses from external exposures are based on factors derived from estinates by Poston and Snyder (1974) of absorbed dose rates in the organs for mononergetic photons eaitted by radicnuclides dispersed uniformly in a seminfinite air space. All radionuclide decay data used in the dose calculations were taken from Kocher (1977).

COWDOS II uses a breathing rate of $0.9 \mathrm{~m}^{3} / \mathrm{h}$ and organ-specific 50-year dose-conversion factors from Dunning et al. (1979) to calculate internal doses from inhalation of radionuclides. Ingestion doses are calculated using input-specified quantities of ingested radionuclides and organ-specific 50-year dose-conversion factors from Dunning et a?. (1979). Both sets of internal dose-conversion factors were derived using a quality factor of 10 for alpha particles. Table 6 is a listing for $241 \mathrm{Am}$ of its radioactive half-life, photon and beta-rarticle spectra, and immersion, inhalation, arid ingestion Hose-conversion factors for nine body omyans and tissues. (The inhalation and ingestion dose-conversion factors for endosteal bone cells are $\sim 2-3$ times higher than thuse for bone, which were used in this assessment.)

Americiun-241 has a radioactive half-life of 433 years and decays by emis:ion of alpha partizies and gamma and $x$-ray photons to ${ }^{237} \mathrm{~Np}$ which has a helf-life of about $2 \times 10^{6}$ years. Neptunium-237 has a lengthy decay chain but, due to its long half-life, would not appreciably affect the dore estimates in this repcrt. Therefore, it was not included in this assessment.

Once inhaled or ingested, ${ }^{241} \mathrm{Am}$ deposited in the lung or the gastrointestinal tract may be absorbed into the blood and distributed to different body organs, principally bone and liver. In ICRP-19 (ICRP, 1972), it is assumed that $45 \%$ of ${ }^{241}$ Am is deposited on bone surfaces, 45\% in the liver, and $10 \%$ in other tissues. Based on animal studies, 


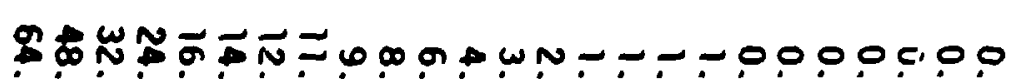

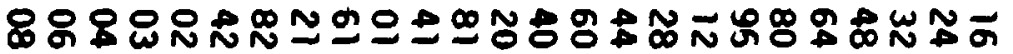

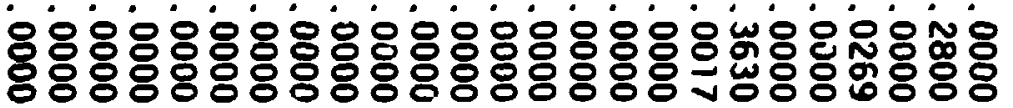

คै

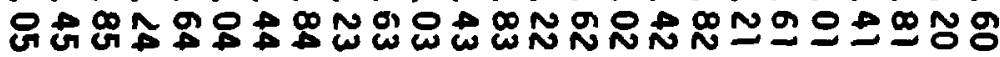

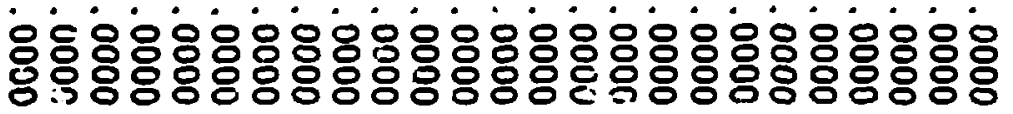

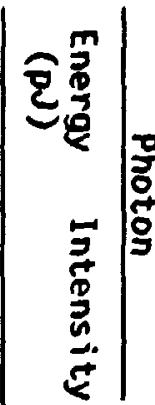

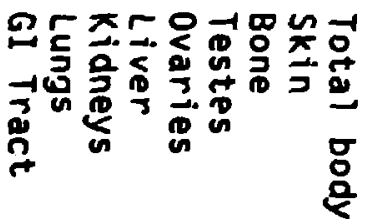

N $\omega \rightarrow \infty \omega \overrightarrow{0} \overrightarrow{0} \dot{\omega}$

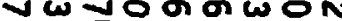

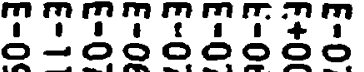
1

$\checkmark \rightarrow+$ on in

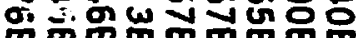
mmmmm

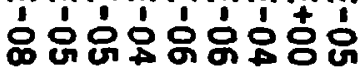

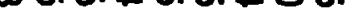

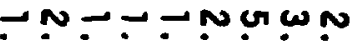

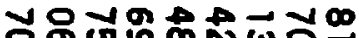

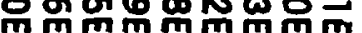
ப்́

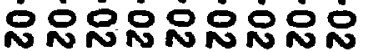


241 An is expected to remain in body organs with half-tiwes ranging between 40 and 100 years.

The inhalation dose-conversion factors were derived (Ounning et a1., 1979) using the International Comission on Radiological Protection (ICRP) task group lung nodel (Horrow et al., 1966) and parameters from ICRP Publication 19 (ICRP, 1972). Retention of radionuclides in organs other than the respiratory tract was modeled by linear ccubinations of up to five decaying exponential functions. The factors used in this assessment correspond to those for particles having activity median aerodynamic diameters of $1.0 \mathrm{~m}$ and the $\mathrm{y}$ solubility classification which has the highest lung dose-conversion factor.

The ingestion dose-conversion factors were derived (Dunning et al. 1979) using a four-segment catenary model of the gastrointestinal (GI) tract (Bernard, 1968) with mean transit times suggested by $E^{\prime}=(1966)$. Retention of radionuc!ides in organs other than the GI tract was modeled using the above mentioned linear combinations of decaying exponential functions.

The source foils used in ICSDs were wodeled as 0.5-cm-dian $x$ $0.0002-c m-t h i c k$ cylinders of a gold plus 241Am mixture covered by a $0.00015-c m-t h i c k$ gold foil. The matrix contains $2 \mathrm{mg} / \mathrm{cm}^{3}$ of $241 \mathrm{Am}$ $\left(2.8 \mathrm{kBq} / \mathrm{cm}^{2}\right)$ or a total activity of $110 \mathrm{kBq}(3 \mu \mathrm{Ci})$. The foils were assumed to be enclosed in a $0.254-\mathrm{cm}$-thick iron housing.

Arrays of detectors (cartons and pallets) were modoled as homngeneous cylinders of a composite material containing $0.28 \mathrm{ng} / \mathrm{cm}^{3}$ of $241 \mathrm{Am}\left(35 \mathrm{~Bq} / \mathrm{Cm}^{3}\right)$. The composite was a homogeneous mixture of $241 \mathrm{Am}$, plastic, cellulose, iron, carbon, and lead that was chosen to approximate exposure rates from an array of point-source detectors in cartons and pallets. The effective density of the composite material was 1.4 $\mathrm{g} / \mathrm{cm}^{3}$. 


\section{DOSE ESTIMATES}

Radiation doses were estinated for annual transport, distribution, use, and disposal of 10 million ICSDs that contain $110 \mathrm{kBq}$ ( $3 \mu \mathrm{Ci}$ ) of 241Am each. We did not estinate doses to workers or the general public during manufacture of the smoke detectors. Rather, we assuned all swoke detectors to originate from suppliers (seven would be required to distribute 10 million detectors under sur assuptions) wo are defined as Individuals licen-ed to manufacture, import, or ake initial distribution for sale of 241 A-containing snoke detectors. In this section, we sumarize the dose estimates and discuss the wore important exposure assuptions used to calculate the doses. External dose eyuivalents are given for total body. Dose equivalents to other organs may be estinated by multiplying the values for total body by the following factors:

$\begin{array}{ll}\text { bone } & -1.93 \\ \text { lungs } & -0.73 \\ \text { kidneys } & -0.63 \\ \text { liver } & -0.60 \\ \text { adximur segment } & \\ \quad \text { of GI tract } & -0.63 \\ \text { testes } & -0.87 \\ \text { ovaries } & -0.61\end{array}$

Appendix A contains detailed tabulations of the exposure conditions. Appendix $B$ contains corresponding tabulations of the dose estimates.

\subsection{Transport of Smoke Detectors}

The transport and distribution schemes used in this study were constructed from information supplied to the NRC by ICSD manufacturers and a summary of procedures and exposure conditions for transport and distribution of consiner products (Etnier and O'Donnell, 1979). We attempted to make relatively simple schemes that encompass a wide range - 
of exposure conditions. Local truck delivery (LO) was assumed to include all deliveries ade within $32 \mathrm{k}$ (20 miles) of the origin. Regional deliveries (RD) were assumed to span 400 kn (250 wiles - a 5-hour drivej; over-the-road deliveries (OTRD) were assuned to span distances greater than $400 \mathrm{~km}$ and to consist of two or wore suciessive regional deliveries. Nost OTRD and P.D trucks were assuned to contain complete shipments that were loaded at the origin and delivered to their destinations witr no intervittent handling at terwinals. Lessthan-truckload (LIL) shipaents were nodeled as composites of unrelated items and were assuned to stop at truck terminals every $\$ 00 \mathrm{~km}$ where they are unloaded and loaded onto other trucks before reaching their final destinaticns.

To estimate doses to workers and the general public during bulk transportation of swoke detectors from suppliers to warehouses, we assumed seven suppliers who distribute a total of 10 million ICSDs per year. Each supplier was assuned to ship 720,000 ssoke detectors to ten chain store warehouses and 720,000 smoke detectors to 100 wolesale warehouses (see Fig. 1). Transportation and distribution schemes differ depending upon the final destination. Eacl, supplier was assuned to send ten shipments per year (7,200 detectors per shipment) to each of ten warehouses (see Fig. 2). Each shipaent was assumed to consist of 50 pallets, each containing 48 cartons (ihree smoke detectors per carton). These shipments kere assumed made as OTRDs and to span average total distances of $1,200 \mathrm{~km}$ (750 miles). Three drivers (one for eaci 400-ka leg) were assumed for each trip (30 drivers per warehouse); each driver was assumed to make ten 400-km trips a year.

The transportation of snoke detectors to wholesale warehouses is outlined in fig. 3. Each of the seven suppliers was assumed to service 100 wholesalers, making five shipments per year (1,440 detectors per shipment) to each warehouse. In all cases a local pickup driver was assumed to carry (I) shipments to a local truck terminal where shipments are handled and loaded on regionai $L T L$ delivery trucks. The trucks were assuned to travel $400 \mathrm{~km}$ (250 miles) to regional cerminals where shipment.s are handled and reloaded onto other regional delivery trucks. This process was assumed to occur three times per shipment. At the 
OANL-DWG 81.0494

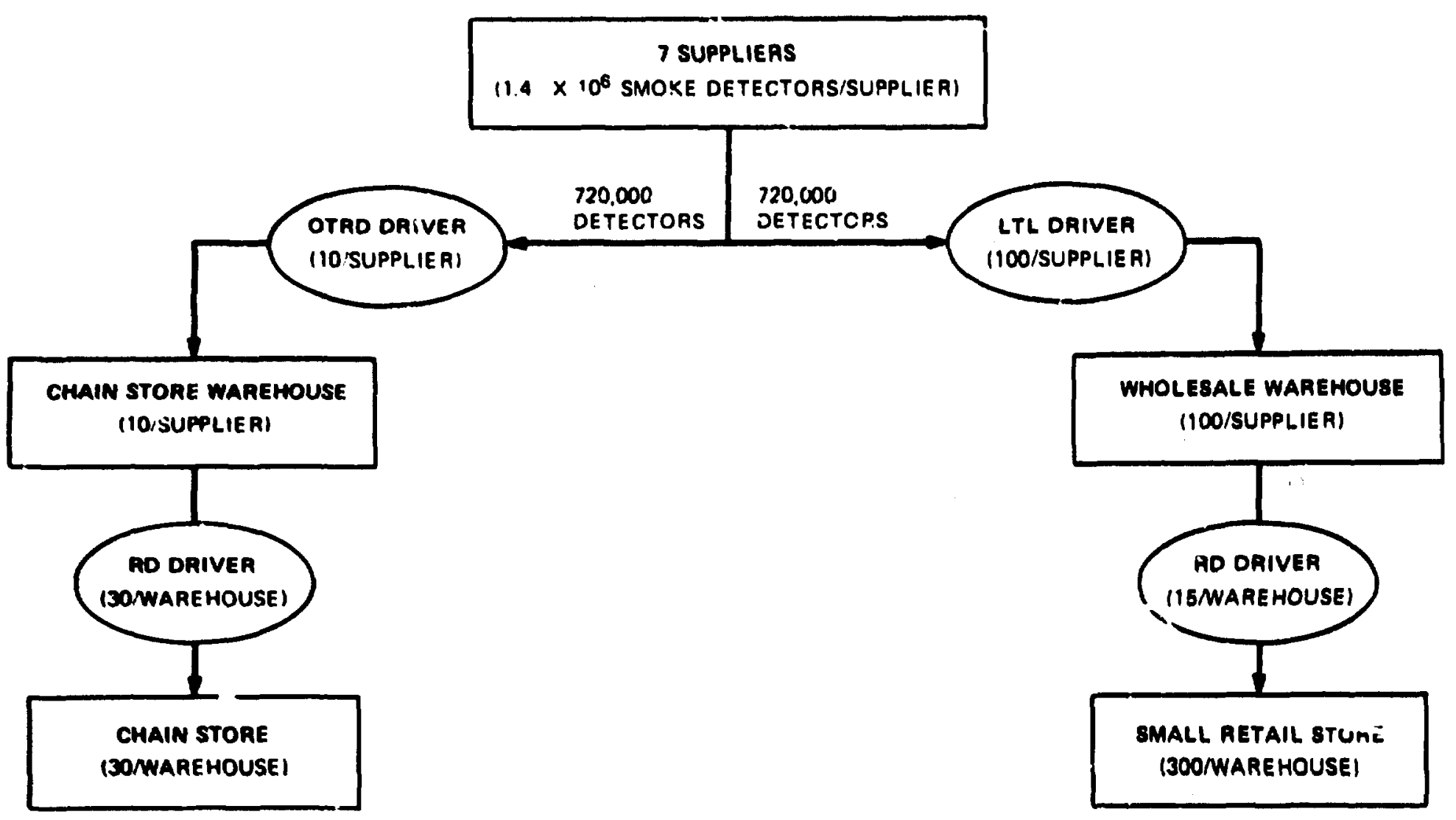

Fig. 1. General view of the transport and distribution of smoke detectors fron supplier to destination. 


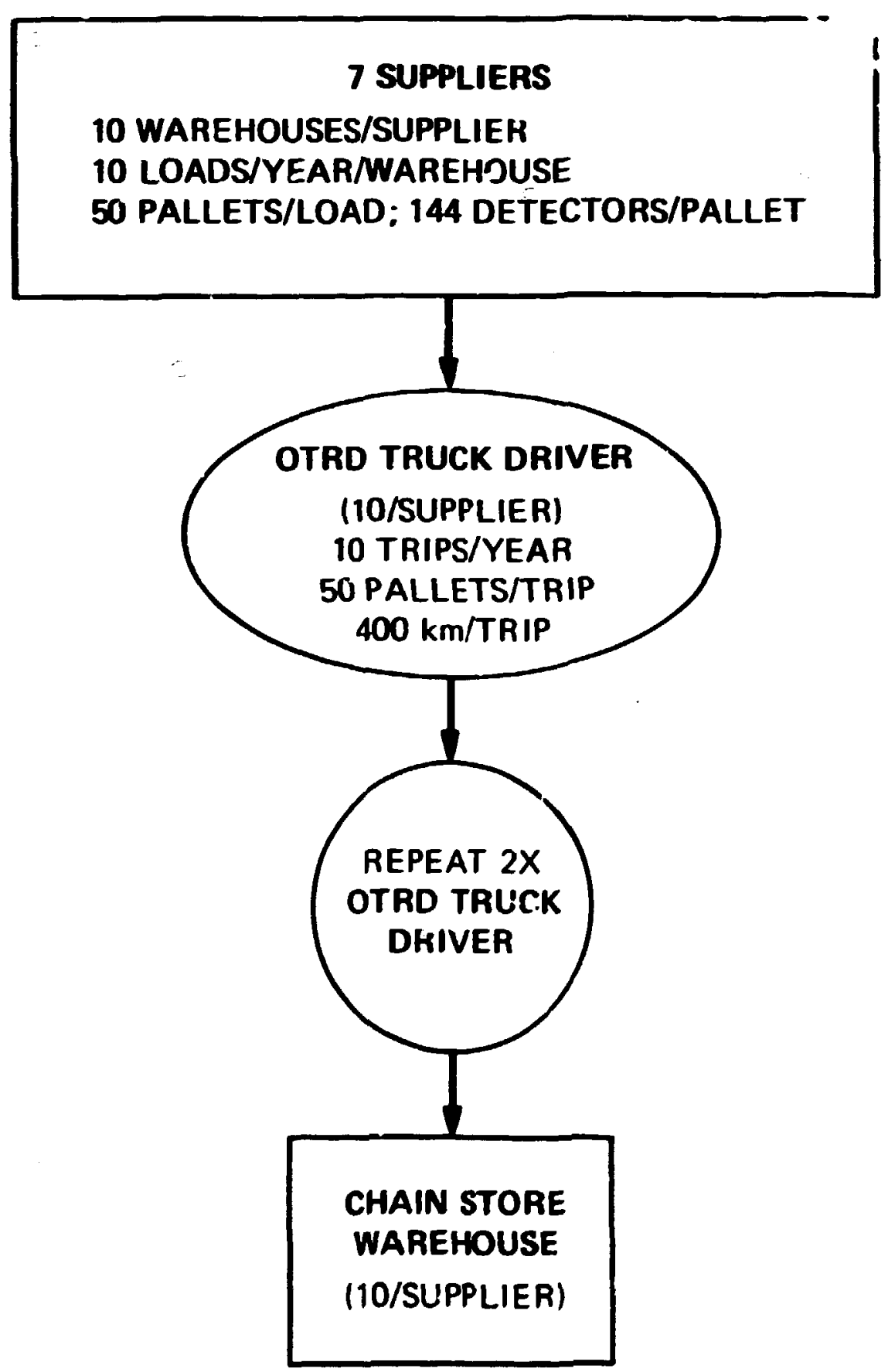

Fig. 2. Flow chart for the transport of 5 million smoke detectors from the supplier to a chain store warehouse. 
oriat-duct orear

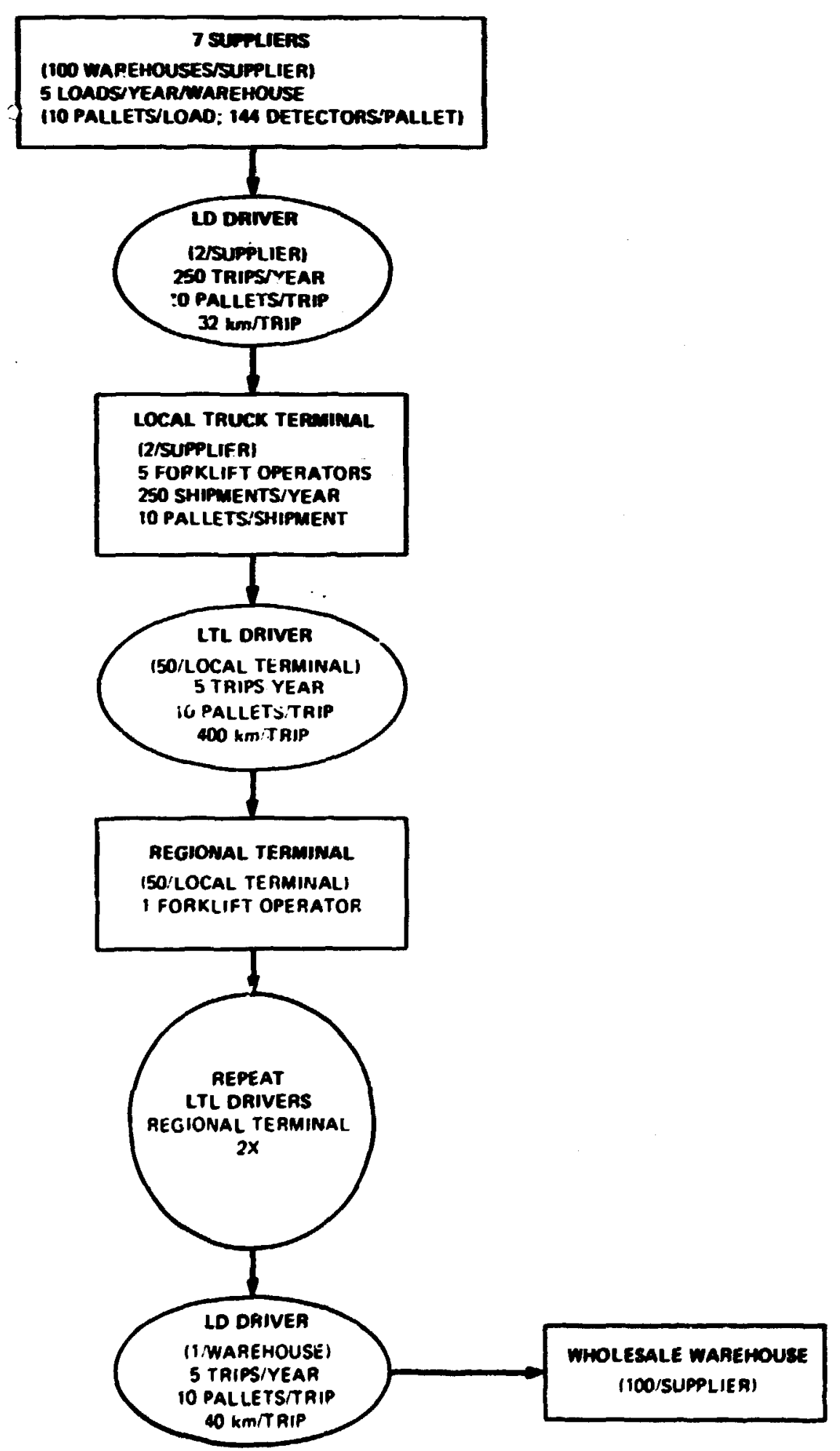

Fig. 3. Flow chart for the transport of 5 million snoke detectors from the supplier to a wholesale warehouse. 
destination terminals, the shipments were assumed loaded onto LD trucks which transport them to the wholesale warehouses (700 warehouses).

Tables A.1 and A.2 list the exprsure conditions assuned for transport of 5 willion swoke detectors from suppliers to chain store warehouses, and 5 million detectors fror suppliers to wholesale warehouses. Tables $B .1$ and $B .2$ give the estimated radiation doses that might be received by truck drivers, temilia! workers and the general public during the two modes of transport considered. Table 7 is a sumary of potential radiation doses to the total body of the various population groups involved in these wodes. The 14 ixcal deliver, drivers who carry smoke detectors to local truck terminais prior to transport to wholesale warehouses could receive the highest total-body dose equiva-

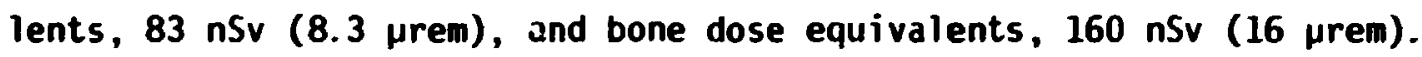
The average total-body dose to all transport workers could be about

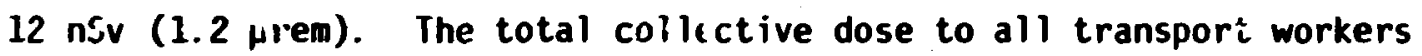
could be 60 person- $\mu S v$ ( 0.006 person-rem).

\subsection{Distribution of Smoke Detectors}

The distribution scheme used for this study complements ihe transportation scheme. We considered: (1) distribution of 5 rilition ICSDs from 70 chain st.ore warehouses to 21,000 chain stores and subsequent $=a l e$ in the stores (Fig. 4), and (2) distribution of 5 million detectors from 700 wholesale warehouses to 210,000 small retail stores and subsequent sale in the stores (see fig. 5).

In both cases, warehouse workers were assumed to handle and work near ICSDs awaiting distribution and to load local or regional delivery trucks that transport the detectors to stores. Stock clerks were assumed to handle and sell detectors from floor displays. Store customers were assumed to be exposed to the disulays.

Tables A.3-A.4 list the exposure conditicis assumed for distribution of the smoke detectors via the two modes discussed. Tables B.3B.4 present radiation doses to total body of individuals and the various groups of persons involved in tice two distribution schemes. 
Table 7. Summary of total-body doses due to transport of smoke detectors

\begin{tabular}{|c|c|c|c|c|c|}
\hline \multirow{2}{*}{ Population group } & \multicolumn{3}{|c|}{ Indiviaual doses, si } & \multirow{2}{*}{$\begin{array}{l}\text { Number } \\
\text { of persons }\end{array}$} & \multirow{2}{*}{$\begin{array}{c}\text { Population doses, } \\
\text { person-Sv }\end{array}$} \\
\hline & Average & Lowest & Highest. & & \\
\hline Truck drivers & $1.7 E-8$ & $1.3 E-8$ & $8.3 E-8$ & $3.0 E+3$ & $5.2 E-5$ \\
\hline $\begin{array}{l}\text { Truck Lerminal } \\
\text { workers }\end{array}$ & $3.8 E-9$ & $2.9 E-9$ & 3. $1 E-8$ & 2. $2 E+3$ & 8. IE-6 \\
\hline $\begin{array}{l}\text { Public on truck } \\
\text { routes }\end{array}$ & $4.5 E-15$ & $8.3 E-16$ & $2.1 E-12$ & 2. $1 E+8$ & $9.5 E-7$ \\
\hline
\end{tabular}


ORNL-DWG 81-6441

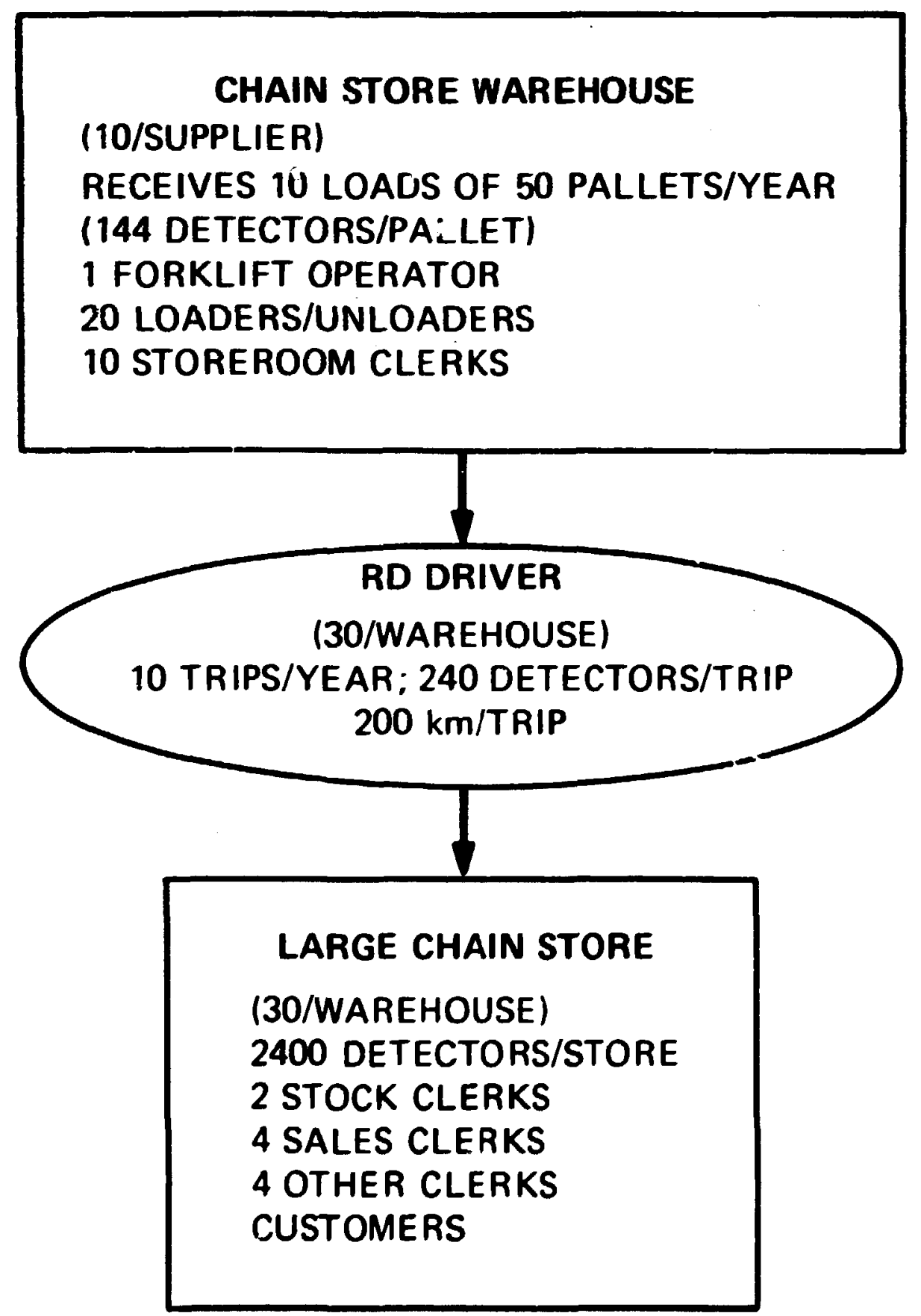

Fig. 4. Flow chart for the distribution of smoke detectors from a chain store warehouse to a large chain store. 
ORNL-DWG 81-6440

WHOLESALE WAREHOUSE
(100/SUPPLIER)
RECEIVES 5 LOADS OF 10 PALLETS/YEAR
(144 DETECTORS/PALLET)
4 UNLOADERS/LOADERS
1 FORKLIF' OPERATOR
5 STOCK HANDLERS

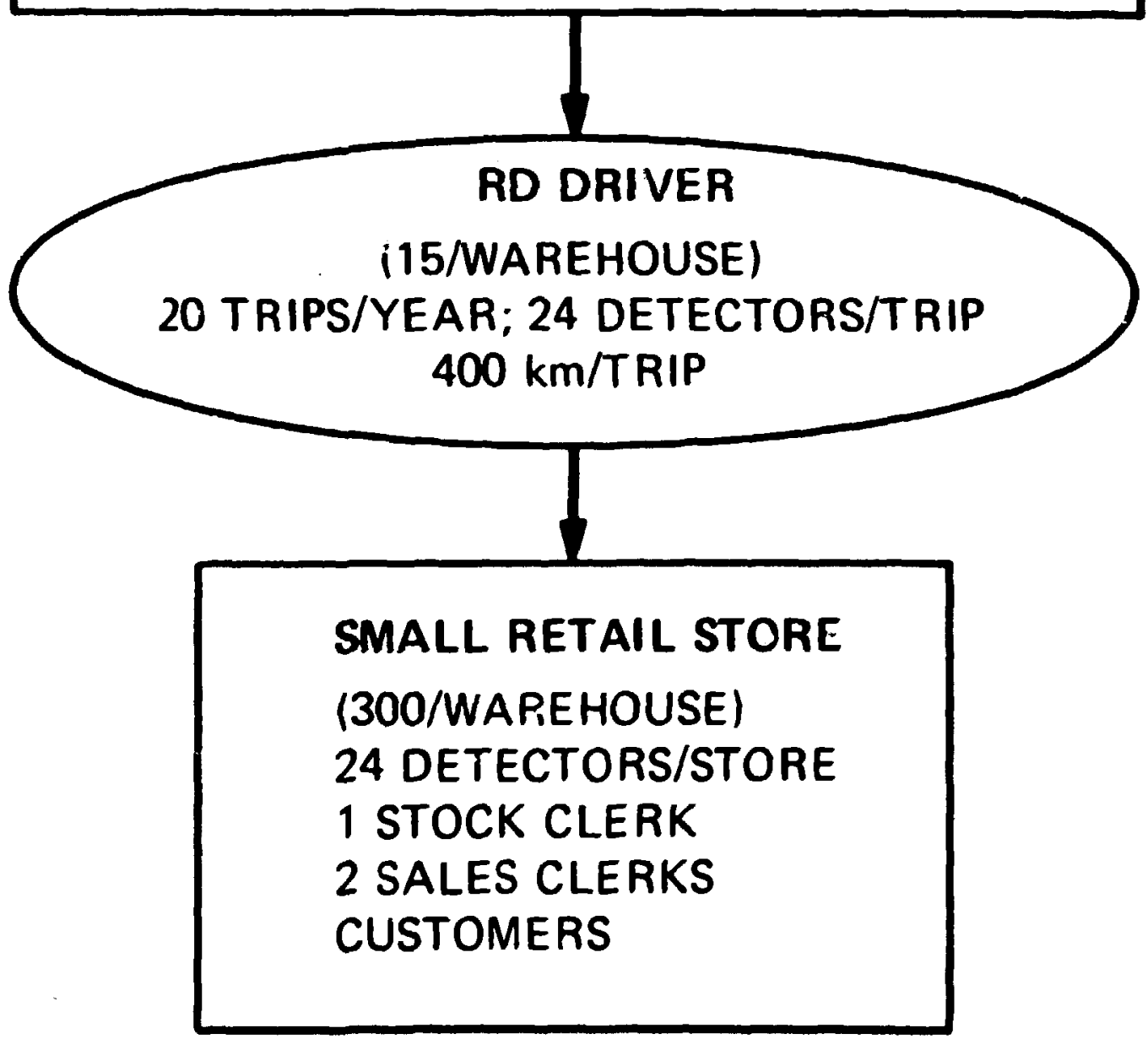

Fig. 5. Flow chart for the distribution of smoke detectors from a wholesale warehouse to small retail stores. 
Table 8 sumarizes tr.e radiation doses to the various groups of individuals.

The individuals who could receive the highest doses to total body during the distribution of smoke detectors were found to be stock handlers working in the wholesale warehouses. These incividuals, who handle cartons of packaged swoke detectors and work near stored cartons, could receive annual total-body doses of ?0 nSv (7 prea). The highest group dose ( 0.11 person-Sv) could be received by store custcmers even though the average individual dose to these customers was found to be relatively low (0.5 nSv). Each customer was assumed to shop $12 \mathrm{~h} / \mathrm{year}$ in a large department store, and $50 \mathrm{~h} /$ year in a small retail store.

\subsection{Use of Swoke Detectors}

For this assessment, we assumed that 10 million ICSDs, each containing $110 \mathrm{kBq}(3 \mu \mathrm{Ci})$ of ${ }^{241} \mathrm{Am}$, are distributed to 5 million huseholds, and calculated doses for one year of use and a one-time purchase and installation. If the ICSOs have a 10-year useful life (as claimed by manufacturers), this set of smoke detectors could deliver the estimated doses for 10 years. Purchase, installation, removal, and disposal occur only once during the 10-year lifetine of an ICSO. Doses from these exposures were found insignificant with respect to doses during use.

Two ICSDs were assumed to be insta led in each home, $10 \%$ in bedrooms and 90\% in halls (Wrenn and Coh'sn, 1979; Belanger et al., 1979). Table 9 lists the exposure conditiris and radiation doses from use in the home of two ICSDs that cortin $110 \mathrm{kBq} 0$ ? $241 \mathrm{Am}$ each.

A homeowner who purcheses, installs, and maintains two smoke detectors in his home, sleeps $8 \mathrm{~h} /$ day, and spends $4 \mathrm{~h} /$ day at other activities in the home could receive an annual dose equivalent to total body of $39 \mathrm{nSv}(3.9 \mu \mathrm{rem})$. A mate, who was assumed to spend $8 \mathrm{~h} / \mathrm{day}$ in the home sleeping and $8 \mathrm{~h}$ at other activities, could receive a dose equivalent to total body of $50 \mathrm{nSv} / y e a r$. Other members of the household could receive $9 \mathrm{nsv} /$ year to total body. 
Table 8. Summary of total-body doses due to distribution of smoke detectors

\begin{tabular}{|c|c|c|c|c|c|}
\hline \multirow{2}{*}{ Population group } & \multicolumn{3}{|c|}{ Individual doses, Sv } & \multirow{2}{*}{$\begin{array}{c}\text { Number } \\
\text { ot' persons }\end{array}$} & \multirow{2}{*}{$\begin{array}{l}\text { Population doses, } \\
\text { person-sv }\end{array}$} \\
\hline & Average & Lowest & Highest & & \\
\hline Warehouse workers & $3.4 E-8$ & $1.3 E-9$ & $7.0 E-8$ & 9. $1 E+3$ & $3.0 E-4$ \\
\hline Truck drivers & $2.2 E-9$ & $1.9 E-9$ & $3.8 t-9$ & $1.3 E+4$ & $2.7 E-5$ \\
\hline Store workers & $1.5 E-8$ & $2.5 E-10$ & 4. $0 E-8$ & $6.5 E+5$ & $9.7 E-3$ \\
\hline Store customers & $5.0 E-10$ & $1.5 E-10$ & 5. $0 E-10$ & 2. $1 E+8$ & $1.1 E-1$ \\
\hline $\begin{array}{l}\text { Public on truck } \\
\text { route }\end{array}$ & $3.6 \mathrm{E}-15$ & $7.5 \mathrm{E}-16$ & 3. $3 E-14$ & 2. $1 E+8$ & $7.6 \mathrm{E}-7$ \\
\hline
\end{tabular}


Table 9. Exposure conditions and radiatio doses from use of two smoke ditectors each containing $110 \mathrm{kBq}$ of $241 \mathrm{Am}$

\begin{tabular}{|c|c|c|c|c|c|}
\hline $\begin{array}{l}\text { Exposed } \\
\text { person }\end{array}$ & $\begin{array}{l}\text { Exposure } \\
\text { activity }\end{array}$ & Source & $\begin{array}{l}\text { Dura ion of } \\
\text { exposure, } \\
\text { h/year }\end{array}$ & $\begin{array}{l}\text { Distance } \\
\text { from source, } \\
\mathrm{cm}\end{array}$ & $\begin{array}{c}\text { Dose equivalent } \\
\text { to total body, } \\
\text { nsv/year }\end{array}$ \\
\hline \multirow[t]{2}{*}{ Homeowner } & $\begin{array}{l}\text { Purchase } \\
\text { Instal } 1 \\
\text { Maintain } \\
\text { Sleep } \\
\text { Other }\end{array}$ & $\begin{array}{l}2 \text { detectors } \\
1 \text { detector } \\
1 \text { detector } \\
1 \text { detector } \\
1 \text { detector } \\
2 \text { detectors }\end{array}$ & $\begin{array}{l}0.5 \\
0.5 \\
0.5 \\
2 \\
2920 \\
2920 \\
1460\end{array}$ & $\begin{array}{r}30 \\
90 \\
30 \\
90 \\
180 \\
600 \\
600\end{array}$ & $\begin{array}{l}0.4 \\
0.05 \\
0.2 \\
0.09 \\
32 \\
3 \\
3 \\
\end{array}$ \\
\hline & Total & & & & 39 \\
\hline \multirow[t]{2}{*}{ Mate } & $\begin{array}{l}\text { Sleep } \\
\text { otlier }\end{array}$ & $\begin{array}{l}1 \text { detector } \\
1 \text { detector } \\
1 \text { detector } \\
1 \text { detector }\end{array}$ & $\begin{array}{l}2920 \\
2920 \\
2920 \\
2920\end{array}$ & $\begin{array}{l}180 \\
600 \\
300 \\
600\end{array}$ & $\begin{array}{r}32 \\
3 \\
12 \\
3 \\
\end{array}$ \\
\hline & Total & & & & 50 \\
\hline \multirow[t]{2}{*}{$\begin{array}{l}\text { other } \\
\text { individual }\end{array}$} & $\begin{array}{l}\text { Sleep } \\
\text { Other }\end{array}$ & $\begin{array}{l}2 \text { drtectors } \\
2 \text { distectors }\end{array}$ & $\begin{array}{l}2920 \\
1460\end{array}$ & $\begin{array}{l}600 \\
600\end{array}$ & $\begin{array}{l}6 \\
3 \\
\end{array}$ \\
\hline & Total & & & & 9 \\
\hline
\end{tabular}


If both ICSDs are located in halls (none in the bedroom), the doses giver: in Table 9 would change as follows:

$$
\begin{aligned}
& \text { Homeowner - from } 39 \mathrm{nSv} \text { to } 10 \mathrm{nSv} \\
& \text { Mate - from } 50 \mathrm{nSv} \text { to } 21 \mathrm{nSv} \\
& \text { Other - unchanged at } 9 \mathrm{nSv} \text {. }
\end{aligned}
$$

To estimate an annual population dose from use of 10 willion ICSDs, the following assumptions were made: (1) $10 \%$ of five willion homes (500 thousand homes) have one detector in the bedroom and one in the hall, as represented by Table 9; and (2) $90 \%$ of the homes (4.5 wi)lion homes) have both detectors in halls, as represented above. This would give an annual collective total-body dose of 0.23 person-siv (23 person-rem).

A total, annual, steady-state, co?lective dose may be estimated by using the above assumptions and assuming 100 million smoke detectors to be in use (this represents a steady tate of 10 million distributed annually, 100 million in use, and 10 million discarded each year). The resulting steady-state collective dose to total body from use would be 2.3 person-Sv for 5 million households.

\section{4 Disposal}

To assess the impact of the disposal of $10 \mathrm{million}$ ICSDs per year, we made several assumptions:

1) a local population group consists of one million persons in 333,333 home units, each housing a family of three;

2) each home unit contains two ICSDs;

3) under steady-state conditions, $10 \%$ of the ICSDs in us 2 will be discarded each year, thus, each set of one million persons will discard 66,666 detectors annually (150 local population groups are required for annual disposal of $10 \mathrm{mitlion}$ ICSL $L_{2}$ ); 
4) of the discarded ICSOs, $900(60,000)$ go directly to land disposal and $10 x(6,666)$ are incinerated and the incinerator residue going to a land disposal site (Brinkerhoff, 1973).

\subsubsection{Waste collection}

Waste collection crews were assumed to consist of two collectors and one driver. Each crew was assumed to service 960 homes per week and collect 192 detectors/year. Approxinately 347 collection crews would be required to service one million persons, and 104,000 collectors and 52,000 drivers would be required to dispose of 10 million ICSDs. Doses to collectors and drivers are sumarized in Table 10. Collectors could receive individual dose equivalents of 2 nSv/year (0.2 $\mu$ rem) to total body and a collective dose equivalent of $\mathbf{2 0 0}$ person-pSv (0.02 person-rea) to total body. Drivers could receive $0.006 \mathrm{nSv} / \mathrm{year}$, and the collective dose to drivers could be 0.3 personHSv/year.

\subsubsection{Land disposal}

Several assessments have been made of possible doses from land disposal of ICSDs (Belanger et al., 1979; Wrenn and Cohen, 1979). These assessments consider leaching into ground water and ingestion of the con'awinated water, leaching into ground water and use of the water to irrigate crops which are subsequently ingested, and uptake of $241 \mathrm{Am}$ by crops planted on old burial sites, dusting of crops with $241 \mathrm{Am}$, etc. All of these assessments, and those that follow, are highly speculative in that they use conservative assumptions based on extrapolated data.

Belanger et al. (1979) made the following assumptions to estimate dose comitments from drinking contaninated ground water:

"1. Ten million ICSDs are disposed of in one year with an average source activity of $3 \mu \mathrm{Ci}(110 \mathrm{kBq})$.

2. Te. percent of ICSOs disposed of in landfills have been previously incinerated and these sources can lose up to ten percent of their initial activity in one year. 
Table 10. Exposure conditions and external rodiation doses to municipal solfd waste collectors from disposal of 10 million smoke detectors containing $110 \mathrm{kBq}$ of $241 \mathrm{Am}$ each

\begin{tabular}{|c|c|c|c|c|c|c|}
\hline $\begin{array}{l}\text { Exposed } \\
\text { person }\end{array}$ & $\begin{array}{l}\text { Number of } \\
\text { individuals }\end{array}$ & $\begin{array}{l}\text { Exposure } \\
\text { activity }\end{array}$ & $\begin{array}{l}\text { Duration of } \\
\text { exposure, } \\
\text { h/year }\end{array}$ & $\begin{array}{c}\text { Distance } \\
\text { from source, } \\
\mathrm{cm}\end{array}$ & $\begin{array}{l}\text { Dose equivalent } \\
\text { to total body, } \\
\text { nSv/year }\end{array}$ & $\begin{array}{l}\text { Collective } \\
\text { dose equivalent } \\
\text { person-sv }\end{array}$ \\
\hline \multirow[t]{2}{*}{ Collectors } & $1.0 E+5$ & $\begin{array}{l}\text { Pick up } \\
\text { waste }\end{array}$ & 4.8 & 30 & 1.9 & $2.0 E-4$ \\
\hline & & $\begin{array}{l}\text { Near } \\
\text { truck }\end{array}$ & 500 & 180 & 2. 3E-2 & $3,4 E-6$ \\
\hline Total & & & & & 1.9 & $2.0 E-4$ \\
\hline Orivers & 5. OE+4 & Driving & 2000 & 180 & $5.7 E-3$ & $3.0 E-7$ \\
\hline
\end{tabular}


3. The rewaining 90 percent of ICSDs lose w to 0.01 percent of source activic; in one year.

4. One-half of the total activity leached from anericiu source; in one year eventually enters the ground water during a similar interval.

5. The volune of leachate generated per year is 90 billion gallons, all of wich enters the ground water systea and is available for withdraval. (This assuption is predicated on the fact that 70 percent of 18,500 solid waste landfill sites in the $U$. S. are in ground water supply areas, and that the average infiltration of precipitation is 10 inches per year.)

C. There is no significant dilution of the zone of contanination from surrounding ground water.

7. One percent of the contaminated water is withdram for domestic water supply and five percent of that amount is consuned as drinking water."

We believe assumption 4 to be unrealistically conservative. Cline (1966) studied the leaching of ${ }^{24} 1 \mathrm{Am}$ in soils under varying conditions of soil pH. His results indicate that after leaching with 100 inches of water (the equivalent of ten-years infiltration of precipitation at ten inches per year) only 26 of the $241 \mathrm{Am}$ was leached from the top one centimeter of acid ( $\mathrm{pH}=4.5$ ) soil and only $24 \%$ was leached from the top centimeter of basic ( $\mathrm{pH}=7.5$ ) soil. The maximu americium penetration of the soil was observed to be 20 centimeters in the basic soil and five centimeters in the acid soil. Using this study (which was based on the equivalent of $\mathbf{1 0}$ years infiltration of precipitation) as indicative of americium behavior in soil, we concluded that $2.5 \%$ of the total activity leached from anericium sources in one year might enter the ground water during that year. Even this is a conservative estimate since Cline's study shows that the maximum americium penetration during the equivalent of 10 years infiltration of precipitation was 20 centimeters. Presumably, most aquifers lie much deeper than 20 cen: iseters below ground surface. 
The results of Belanger et al. (1979) were scaled to watch our assumptions (i.e., 10 villion ICSOs discarded per year in iand fills and $\mathbf{2 . 5 5}$ of the total asericiu activity leachei into ground $w$ ter during that year). The resulting 50-year dose comitments frow driaking $370 \ell$ of contaminated water per year (and those calculated using the assuptions of Belanger et al. and our dose-conversion factors) are given in Table 11. The individual estimated to receive the highest. cose comitments (under the assuptions of belanger et al.) could receive $2.6 \mu S v(0.26$ mrea) to total body and $30 \mu S v$ to bone. The average individual (under our codifirations to the assuptions of Belanger et al.) could receive 0.13 uSv to total body and $1.6 \mu \mathrm{Sv}$ to bone. Ingestion of contaminated ground water could yield collective doses of 0.061 person-Sv (6.1 person-rem) and 0.72 bone-5r.

Using the assumptions of Belanger et al. (1979) for ingestion of crops irrigated with contaminated water and our $2.5 \%$ leach assimption,

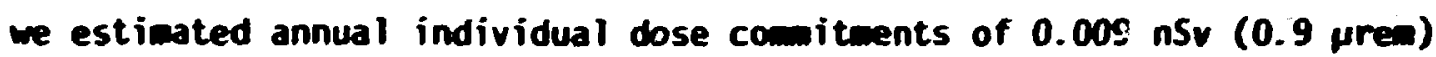
to total body and $0.1 \mathrm{nSv}$ to bone (Table 11). Corresponding collective dose comitments were 0.002 person-Sv ( 0.2 person-rea) and 0.02 bone-Sv.

If the fraction of environmentally dispersed 241 in that is ultimately ingested by man is $10^{\circ}$ (Urenn and Cohen, 1979) and $10 \%$ of the annually disposed $241 \mathrm{Am}(0.11 \mathrm{TBq})$ is so dispersed, about $110 \mathrm{kBq}$ coula be ingested. This could produce collective dose comitments of 0.05 person-Sv and 0.6 bone-Sv. The average individual could receive 0.2 nSv to total body and 3 nSv to bone (Table 11).

To estimate potential doses from ingestion of crops grown directly on landfills, we assuned all the discarded $241 \mathrm{Am}$ (1.1 TBq) to be uniformly dispersed within the top $20 \mathrm{~cm}$ of soil (density $=1.5 \mathrm{~g} / \mathrm{cm}^{3}$ ) of the $2000 \mathrm{~km}^{2}$ (500 thousand acres) of currently used landfill (Belanger et al., 1979). The resulting concentration of $241 \mathrm{Am}$ in the soil would be $1.8 \mathrm{mBq} / \mathrm{g}$. Assuming the $241 \mathrm{hm}$ content of plants to be 0.0001 that of soil and an annuai dietary plant intake of $3650 \mathrm{~g}$ (Wrenn and Cohen, 1979), a person eating plants grown on old landfills could ingest $0.67 \mathrm{mba}$ of $241 \mathrm{Am}$. Such a person was estinated to recefve 50-year dose commitments of 0.29 nSv to total body and $3.4 \mathrm{nSv}$ to bom (Table 11 ). To estimate a population dose from ingestion of plants grown on old 
Table 11. Radiation doses to individuals and populations from land disposal of 10 intllion 241 Am-containing smoke detectors

\begin{tabular}{|c|c|c|c|c|c|c|c|}
\hline \multirow{2}{*}{$\begin{array}{l}\text { Exposure } \\
\text { pathway }\end{array}$} & \multirow{2}{*}{$\begin{array}{c}\text { Intake per } \\
\text { year } \\
(m B q)\end{array}$} & \multicolumn{2}{|c|}{$\begin{array}{c}\text { Individual } \\
\text { dose commitment } \\
\text { (nSv) }\end{array}$} & \multirow{2}{*}{$\begin{array}{l}\text { Intake per } \\
\text { year } \\
(k B(1)\end{array}$} & \multicolumn{2}{|c|}{$\begin{array}{c}\text { Collective } \\
\text { dose commitment } \\
\text { (person-Sv) } \\
\end{array}$} & \multirow{2}{*}{ References } \\
\hline & & Total body & Bone & & Total body & Bone & \\
\hline \multicolumn{8}{|l|}{ Ingestion } \\
\hline $\begin{array}{l}\text { leach water } \\
\text { - highest } \\
\text { - typical }\end{array}$ & $\begin{array}{l}5920 \\
3.04\end{array}$ & $\begin{array}{r}2600 \\
130\end{array}$ & $\begin{array}{r}30,000 \\
1,600\end{array}$ & 140 & 0.061 & 0.72 & $\begin{array}{l}\text { Belanger } \\
\text { Belanger, } \\
\text { modified }\end{array}$ \\
\hline irrigated crops & 0.020 & 0.0086 & 0.10 & 4.2 & 0.0018 & 0.022 & $\begin{array}{l}\text { Belanger, } \\
\text { modtfied }\end{array}$ \\
\hline crops, general & 0.52 & 0.22 & 2.7 & 110 & 0.048 & 0.57 & $\begin{array}{l}\text { Wrenn and } \\
\text { Cohen }\end{array}$ \\
\hline $\begin{array}{l}\text { crops grown on } \\
\text { landfill }\end{array}$ & 0.67 & 0.29 & 34 & 14 & 0.0061 & 0.072 & $\begin{array}{l}\text { Wrenn and } \\
\text { Cohen }\end{array}$ \\
\hline burning & $a$ & 0.0015 & 0.018 & $a$ & 0.00023 & 0.0027 & See text \\
\hline \multicolumn{8}{|l|}{ Inhalation } \\
\hline $\begin{array}{c}\text { resuspended } \\
\text { particles }\end{array}$ & 2.4 & 60 & 010 & $a$ & $a$ & $a$ & $\begin{array}{l}\text { Wrenn and } \\
\text { Cohen }\end{array}$ \\
\hline burning & $a$ & 0.0013 & 0.014 & $a$ & 0.00020 & 0.0021 & See text \\
\hline
\end{tabular}

\footnotetext{
a Not estimated."
} 
landfills, we assuned $10 \%$ of the population ( 21 million persons) to behave as the above individual. This yielded population dose comitwents of 0.0061 person-Sv and 0.072 bone-Sv from ingestion of $14 \mathrm{kBq}$ of 241 An.

Another potential exposure pathway near landfills is resuspension of uncovered $241 \mathrm{Am}$. Johnson finds the average concentration of uraniu resuspended in air above soil that contains $1 \mathrm{~Bq}$ of uraniud/g of soil to range between 3.5 and $540 \mu \mathrm{Bq} / \mathrm{m}^{3}$ (as reported in Wrenn and Cohen, 1979, and Belanger et al., 1979). Assuming that resuspension of anericium and uraniu are similar and that landfill soils contain $1.8 \mathrm{~m} \mathbf{m} / \mathrm{g}$ of $241 \mathrm{Am}$, we estimated the average, steady-state concentration of resuspended $241 \mathrm{Am}$ to range between 0.0064 and $1.0 \mu \mathrm{Bq} / \mathrm{m}^{3}$. Using the higher value and assuming a breathing rate of $1.2 \mathrm{~m}^{3} / \mathrm{h}$ and exposures during 250 eight-hour days, we estimated an annua! intake (via inhalation) of $2.4 \mathrm{mBq} /$ year. Such exposures could yield individual 50-year dose ccmitments via inhalation of approximately $60 \mathrm{nSv}$ to total body, 610 nSv to bone, and 200 nSv to lungs (Table 11). We did not estimate potential collective doses from resuspension because we felt that very few persons would be at a landfill for $8 \mathrm{~h}$ of each workday.

Since only $6 \%$ of the 12,000 land disposal sites sperating in the United States during 1967 were classifiec as sanitary landfills (General Electric Company, 1975), another potential source of public exposure is airborne ${ }^{241}$ An released by burning at landfills. To estimate potential doses via this pathway, we assumed 66,666 ICSDs containing 7.4 GBq of 241An to be discarded during one year at one landfill. We further assumed 0.0018 of the discarded $241 \mathrm{Am}(74 \mathrm{kBq})$ to become airborne during burning (Cutshall et al., 1978, find typical releases of $0.01 \%$ at $1200^{\circ} \mathrm{C}$ and about an order of magnitude lower releases at $600-900^{\circ} \mathrm{C}$ ). Using the same assumptions regarding dispersion and intake of the released material as were used for incineratsrs (see Sect. 4.4.3), we estimated that the average individual could receive 1.3 pSv to total body, $14 \mathrm{pSv}$ to bone, and $4.7 \mathrm{pSV}$ to lungs via inhalation; $1.5 \mathrm{pSv}$ to total body, $18 \mathrm{pSv}$ to bone, and $0.00012 \mathrm{pSv}$ to lungs via tngestion. Population doses from burning $10 \mathrm{~m}$ illion ICSDs were estimated to be 0.00020 person-Sv (total body), 0.0021 bone-Sv, and 0.00071 lung-Sv via 
inhalution; 0.00023 person-Sv, 0.0027 bone-Sv, and 0.18 lung-nSv via ingestion (Table 11).

\subsubsection{Incineration}

To estimate potential radiation doses from incineration of ICSDs, we assumed incineration of 6666 ICSDs per year in one incinerator that services one million persons. (Approximately 150 such incinerators would be required to incinerate 10 million ICSUs per year.) The incinerator was assumed to have a 15-m-high stack and an 15-m/s effluent release velocity. Inhalation and ingestion doses were calculated with the AIRDOS-II computer code (Hoore, 1977) using average meteorological conditions (USAEC, 1974) and internal radiation dose conversion factors from Killough et al. (1978). A $10 \%$ release of particulates out the stack was assumed. Cutshall et al. (1978); EAD Metallurgical (1977); Hall and Hunt (1975 and 1978); and Niemeyer (1969) r.ive measured the release of $241 \mathrm{Am}$ from source foils and whole ICSDs during high temperature tests. The range of reported values is:

foils only: $0.006-0.3 \%$;

whole detectors: $0.003-0.2 \%$.

For this assessment we assumed $0.2 \%$ of the $110 \mathrm{kBq}(3 \mu \mathrm{Ci})$ per detector to become airborne and $10 \%$ of this to be released from the stack. This resulted in a postulated release of $140 \mathrm{kBq}(4 \mu \mathrm{Ci})$ of ${ }^{241} \mathrm{Am}$ from each incinerator stack per year.

Collective dose estimates to total body, bone, and lungs from inhalation and ingestion are listed in Table 12 . These doses were calculated assuming each person to remain near the incinerator and to eat food raised within $80 \mathrm{~km}(50 \mathrm{mi})$ during the entire year. The average individual could receive $5.8 \mathrm{pSv}(0.58 \mathrm{nrem})$ to total body, $65 \mathrm{pSv}$ to bone, and $9.5 \mathrm{pSv}$ to lungs. The maximally exposed individual could receive $3.8 \mathrm{nSv}(0.38 \mu \mathrm{rem})$ to total body, $43 \mathrm{nSv}$ to bone, and $7.0 \mathrm{nSv}$ to lungs. Total collective doses to a population of 150 million persons around 150 incinerators was estimated to be 0.87 person-mSv $(0.087$ person-rem), 9.7 bone-mSv, and 1.4 lung-mSv. 
Table 12. Population dose estinates for airborne release of $100 \mathrm{kBq}$ of ${ }^{241 \mathrm{Am}}$ from an incinerator stack ( 1 million persons)

\begin{tabular}{|c|c|c|}
\hline Organ & Exposure pathway & $\begin{array}{l}\text { Collective dose } \\
\text { (person-Sv) }\end{array}$ \\
\hline \multirow[t]{3}{*}{ Total Body } & Inhalation & $2.7 E-6$ \\
\hline & Ingestion & 3. $1 E-6$ \\
\hline & Total & $5.8 E-6$ \\
\hline \multirow[t]{3}{*}{ Bone } & Inhalation & $2.8 E-5$ \\
\hline & Ingestion & $3.7 E-5$ \\
\hline & Total & $6.5 E-5$ \\
\hline \multirow[t]{3}{*}{ Lungs } & Inhalation & $9.5 E-6$ \\
\hline & Ingestion & $2.4 E-10$ \\
\hline & Total & $9.5 E-6$ \\
\hline
\end{tabular}




\subsection{Fires}

To estimate 50-year dsse comitments to firefighters from combating residential and warehouse fires, we made the following assumptions:

1. During a fire, 0.25 of the $241 \mathrm{Am}$ present in the building becomes airborne as 1-pm-dian particles. This assumption maximizes the calculated dose comitments because it uses the highest total $241 \mathrm{Am}$ release fraction found during temperature testing at $1200^{\circ} \mathrm{C}$ (Cutshall et al., 1978).

2. All firemen who enter a burning building use selfcontained breathing apparatus (Oak Ridge Fire Department, 1981). These apparatus allow no more than 12 of the air breathed by firemen to come from the air in the burning building.

3. The air intake rate for firemen is $1.2 \mathrm{~m}^{3} / \mathrm{h}$ (U. S. Department of Health, Education, and Helfare, 1970).

4. The burning buildings have a ventilation rate of one building volume per hour, an undoubtedly low ventilation rate.

5. Firefighters enter the burning buildings at the instant that the 241Am is released and remain in the building for $8 \mathrm{~h}$. This is a conservative assumption because it is rare that a firefighter would remain in a burning building during a continuous 8-h period and because potential dose commitments from being in a burning building are time dependent (see Table 13). Delayed entry into the building could reduce the calculated dose comitments significantly (e.g., a 1-h delay could reduce doses to $37 \%$ of those given; a 2-h delay, to 14\%).

\subsubsection{Residentia, fíres}

Under the preceding assumptions, a firefighter combating a fire in a residence containing two ICSDs and having a volume of $450 \mathrm{~m}^{3}$ could inhale $0.012 \mathrm{~Bq}(0.32 \mathrm{pC} i)$ of $241 \mathrm{Am}$. The corresponding 50-year dose 
Table 13. Time-dependent fraction of 8-hour dose comitment received by individuals during fire

\begin{tabular}{cc}
\hline Hour & $\begin{array}{c}\text { Fraction of } 8-h \\
\text { dose delivered }\end{array}$ \\
\hline $0-1$ & 0.63 \\
$1-2$ & 0.23 \\
$2-3$ & 0.086 \\
$3-4$ & 0.032 \\
$4-5$ & 0.012 \\
$5-6$ & 0.0043 \\
$6-7$ & 0.0016 \\
$7-8$ & 0.00058 \\
\hline
\end{tabular}


comitments would be $0.28 \mu S v(0.028$ mrea) to total body, $3.0 \mu S v$ to bone, and $1.0 \mu \mathrm{Sv}$ to lungs. If the firefighter enters the residence after the fire has progressed for $1 \mathrm{~h}$ and rewains for $7 \mathrm{~h}$, he would receive only $37 \%$ of the 8 -h dose comitwents given above.

It has beer estimated that there could be 7000 fires per year that might involve release of ${ }^{241} \mathrm{Am}$ from smoke detectors (USNRC, 1978). Assuing 7000 firefighters (one near the burning ICSDs in each home), we estimated population doses of 0.0020 person-Sv (0.20 person-rea) to total body, 0.021 bone-Sv ( 2.1 bone-rea), and 0.0070 lung-Sv ( 0.70 lungrem).

\subsubsection{Warehouse fires}

Warehouse fires are not commol, and we believe the probability is very low that a warehouse containing a large quantity of ICSDs will burn. Therefore, although we made individual dose estimates for firefighters, we did not make a population dose estimate.

A chain warehouse was assumed to have a volume of $3000 \mathrm{~m}^{3}$ and to contain 3600 ICSDs (see Sects. 4.1 and 4.2) which could release $800 \mathrm{kBq}$ of $241 \mathrm{Am}$ during a fire that burned all of them. Using the assumptions and conditions mentioned above, we estimated a firefighter to inhale $3.2 \mathrm{~Bq}$ of $241 \mathrm{Am}$. Such a firefighter could receive a total-body dose commitment of $75 \mu \mathrm{Sv}$ ( $7.5 \mathrm{mrem})$, a bone dose commitment of $800 \mu \mathrm{Sv}$ (80 mrem), and a lung dose commitment of $270 \mu S v$ (27 mrem). As before, these estimates may be reduced depending on the time and duration of building entry.

\subsubsection{Cleanup after fire}

Cleanup after a fire in a residence or a warehouse was assumed to require $\mathfrak{c} h$, and cleanup personnel were assumed to wear no respiratory equipment. Cutshall et al. (1978) measured the powdery (transportable) rasidue $(32 \mathrm{~g})$ from heating an ICSD to $1200^{\circ} \mathrm{C}$, and find that the activity contained in particles with diameter's less than or equal to $10 \mu \mathrm{m}$ to be $\sim 0.0014$ of the source activity. We assumed 1 wt $\%$ of the particles in the residue to have a diameter of $1 \mathrm{\mu m}$. Therefore, the average 
content of 1-pim-dia particles in the transportable residue left by burned ICSDs would be $0.048 \mathrm{~Bq} / \mathrm{g}(110 \mathrm{kBq} \times 0.0014 \times 0.01 / 32.1 \mathrm{~g})$.

We estinated potential dose comitments from cleanup by using the findings of Johuson and Cutshall et al. (1978). Johnson ejtimates airborne concentrations of uranium resuspended from soils to range between 3.5 and $540 \mu \mathrm{Bq} / \mathrm{m}^{3}$ per becquerel per grain of soil (see Sect. 4.4.2). From Cutshall, we estimated the transportable residue from burned ICSOs to contain $0.048 \mathrm{~Bq}$ of ${ }^{241} \mathrm{~A} / \mathrm{g}$. Using Johnson's higher estimate, the airborne concentration of respirable $241 \mathrm{Am}$ could be $26 \mu \mathrm{Bq} / \mathrm{m}^{3}$. Breathing at a rate of $1.2 \mathrm{~m}^{3} / \mathrm{h}$ for $8 \mathrm{~h}$ could resc $t$ in an intake of $0.25 \mathrm{mBq}$ of $241 \mathrm{Am}$. The resulting 50-year dose comitments due to inhalation could be $6.0 \mathrm{nSv}(0.60 \mu \mathrm{rem})$ to total body, $64 \mathrm{nSv}$ (6.4 urem) to bone, and $21 \mathrm{nSv}$ ( $2.1 \mu \mathrm{rem}$ ) to lung. Since it is highly unlikely that an individual would remain near the rubble of burned ICSDs for $8 \mathrm{~h}$ and Johnson's assumptions apply to a large contaminated-surface area (here we have relatively small contaminated surface areas), doses from cleanup would most likely be much lower than the above estimates. This would be especially true for cleanup after residential fires.

Collective dose estimates from cleanup after 7000 residential fires under the preceding assumptions were 42 person- $\mu S v$ ( 4.2 person-mrem) to

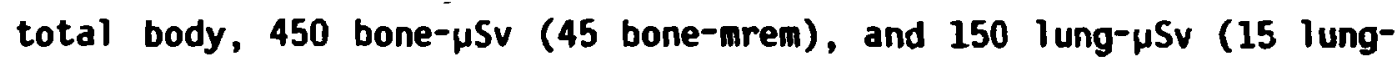
mrem).

\subsection{Ingestion of Source Foils}

Under normal conditions of distribution, use, and disposal of ICSDs, the ${ }^{241}$ Am-containing source folls are inaccessibie. However, a determined individual could remove the foils (probably by destroying the ICSD) and subsequently ingest them. To estimate potential dose commitments from such an event, we used data obtained from a study of an ICSD assembler who swallowed two foils which contained $\sim 70$ and $90 \mathrm{kBq}$ ( 1.9 and $2.4 \mu \mathrm{Ci}$ ) of $241 \mathrm{Am}$ (Rundo et a1., 1977). This study concludes that, despite unusually long durations in the GI tract ( 16 and $24 \mathrm{~d}$ ), the foils lost $<1 \%$ of their original activities and $<1.5 \%$ of the lost activity entered the blood and body organs. 
To estieate potential 50-year dose comitments irom ingestion of foils contalning $110 \mathrm{kBq}(3 \mu \mathrm{Ci})$ of $241 \mathrm{Am}$, we assuned $\mathrm{L}$ of the activity to escape from the foils. This would be equivalent to ingestion of $\sim 1.1 \mathrm{kBq}$ of $241 \mathrm{Am}$. This could give 50-yecr dose comitments of $0.48 \mathrm{mSv}$ (48 mrem) to total body and $5.7 \mathrm{mSv}$ (570 mrem) to bone. 


\section{REFEREACES}

Belanger, R., D. H. Buckley, and J. B. Swenson. 1979. Environmental Assessment of Ionization Chamber Smoke Detectors Containing Am-241. NUREG/CR-1156.

Brinkerhoff, R. J. 1973. Inventory of interwediate-size incinerators in the United States - 1972. Pollution Eng. 5(11):33-38.

Cline, J. F. 1966. Uptake of Am-241 and Pu-239 by Plants. BMul-CC925.

Code of Federal Regulations. 1980. Title 10 - Energy. Chapter I Nuclear Regulatory Comnission. Part 30 - Rules of General Applicability fo Domestic Licensing of Byproduct Material. Section 30.20 - Gas and Aerosol Detectors Containing Byproduct Material.

Cutshall, N. H., I. L. Larsen, and F. K. Case. 1978. High Temperature resting of Smoke Detector Sources. NUREG/CR-0403 (ORNL/NUREG/TM246).

Dunning, D. E., Jr., S. R. Bernard, P. J. Walsh, G. G. Killough, and J. C. Pleasant. 1979. Estimates of Internal Dose Equivalent to 22 Target Organs for Radionuclides Occurring in Routine Releases from Nucleir Euel-cycle Facilities, Vol. II. NUREG/CR-0150, Vol. 2; ORNL/NUREG/TM-190/V2.

EAD Metallurgical. 1977. "Test Results for Foil Integrity." Attachment to letter to U.S. Nuclear Regulatory Commission. November 10, 1977.

Etnier, E. L., and F. R. O'Donne11. 1979. A Sumary of Procedures Used to Transport and Distribute Consumer Products. ORNL/TM-6675.

General Electric Company. 1975. Solid Waste Management Technology Assessment. Vankostrand Reinhold Company. New York.

Hal1, E. G., and D. G. Hunt. 1975. A Swmary of an Integrity Testing Progranme on Alpha Poils Used in Ionization Smoke Detectors. TRC Report No. 378. Amersham. The Radiochemical Centre, Ltd.

Hall, E. G., and D. G. Hunt. 1978. Integrity testing of radioactive sources used in consumer products. In Radioactivity in Conowmer Products, ed. A. A. Moghissi et al., Pp. 398-422. NUREG/CP-0001. 
ICRP Comittee 2 Task Group. 1972. The metabolism of compounds of plutonium and other actinides. ICRP Publication 19, Perganon Press, 0xford.

ICRP Comaittee 2 Task Group. 1967. Deposition and retention models for internal dosimetry of the human respiratory tract. Errata and revisions to repcrt. Bealth Phys. 13:1251.

Killow Th, 6. G., D. E. Dunning, Jr., S. R. Bernard, and J. C. Pleasant. 197.. Estimates of Internal Dase Equivalent to 22 Target Organs for Radionuclides Occurring in Routine Releases from Huclear PuelCycle Pacilities, Vol. II. MUREG/CR-0150 (ORRL/IUREG/TH-190).

Kocher, D. C. 1977. Huclear Decay Data for Radionuclides Occurring in Routinz Releases frm Auclear Puel Cycle Pacilities. ORM/MUREG/ TIH-102.

Kocher, D. C. 1980. Dose-rate conversion factors for external exposure to photon and electron radiation from radionuclides occurring in routine releases from nuclear fuel cycle facilities. Health Phys. 38(4; ;:543-621.

Moore, R. E. 1977. Tine AIRLOS-II Computer Code for Estimating Radiatio. Doses to Man from Airborme Radionuclides in Areas Surrounding Nhclear Eacilities. ORNL-5245.

Morrow, P. E., D. V. Bates, B. R. Fish, T. F. Hat ih, and T. T. Mercer. 1966. Deposition and retention models for internal dosimetry of the human respiratory tract. Health Phys. 12:173-207.

Niemeyer, R. G. 1969. Containment Integrity of ${ }^{226} R a$ and ${ }^{241} \mathrm{Am}$ Foils Employed in Smoke Detectors. ORNL/TM-2684.

Oak Ridge Fire Department. 1981. Telephone conversation between Chief McMahon and F. R. O'Donnell wich revealed that almost a!l firemen, when entering or working near a burning building, wear selfcontained breathing apparatus which are at least $99 \%$ effective in excluding ambient air from breathing air.

O'Donnell, F. R. 1978. Assessment of Radiation Doses from Radioactive Materials in Consumer Products - Methods, Problems and Results. In Radioactivity in Conowner Products, ed. A. A. Moghissi, et al., pp. 241-52. NUREG/CP-0001. U. S. Nuclear Regulatory Commission, Washington, D.C. 
O'Donnell, F. R., D. C. Kocher, O. U. Burte, and F. H. Clark. 1981. CanDas-II - A Tool for Botimating Radiation Doses fran Radia ractide-Containing Consaner Products. MREG/CR-2068; 0.iu/MREG/ Th-454.

Organization for Economic Cooperation and Development. Muclear Energy Agency. 1977. Recomendations for Ionization Chaber Sucke Detectors in Inplenentation of Radiation Protection Standards.

Poston, J. U., and U. S. Snyde:. 1974. A model for exposure to a semiinfinite cloud of a photon exitier. Health Fhys. 26(4):287-293.

Rundo, J., U. D. Fairman, H. Essling, and P. R. Huff. 1977. Ingestion of $241 \mathrm{~h}$ sources intended for domestic swoke detectors: report of a case. Health Phys. 33(6):561-566.

U.S. Atomic Energy Comission (USAEC). 1974. Apoendix II.I: Assumtions and Hodels Used to Assess Environmental Effects. In Brwironmental Statement on Liquid Metal Past Breeder Reactor Program, Yo1. 2. WASH-1535.

U.S. Department of Health, Education, and Velfare. 1981. Radiological Health Handbook. Rockville, Maryland.

U.S. Muc?ear Regulatory Conission. 2978. "An Interia Staff Analysis of the Environmental Effects of Ionization Type Smoke Detectors." Unpublished staff report by Transportation and Product Standards Branch. Contact D. A. Sinith.

Urenn, M. E., and N. Cohen. 1979. Assessment of Risks and Benefits of Home Ionization-Type Snoke Detectors. Draft report prepared for the Ionization Sinoke Detector Bureau of the Mational Electrical Manufacturers' Association. 
APPEMIX A

DETAILED taBuLATIONS OF EXPOSURE COMDITIONS 
DETAILEO TABULATIOAS OF EXPOSURE COMDITIOAS

The following definitions will be useful for interpreting the headings of Tables A.1-A-4:

TIVE

duration $(h / y)$ of exposure,

AIR:

comc airborne concentration $\left(\mathrm{g} / \mathrm{cm}^{3}\right)$ of radionuclides,

RADIUS radius $(C)$ of the air space,

ANT ING

mass (g) of ingested radionulides.

SOURCE:

DESCRIPIION source description.

G

source geometry index nuber ( 1 indicates a point source; 11 indicates a cylindrical source),

M scurce nateria) index number (14 = composite material used to represent cartons and pallets of smoke detectors).

MSS mass of thorium in the source (in $\mathrm{g}$ if $\mathrm{G}=1 ; \mathrm{g} / \mathrm{cm}^{3}$ if $\mathrm{G}=11$ ),

LEMGTH length $(\mathrm{cm})$ of a cylindrical source,

RADIUS radius $(\mathrm{cm})$ of a cylindrical source,

DISTANCE distance $(\mathrm{cm})$ between source and exposed persons,

ABSORBER:

DESCRIPTION absorber description,

M aosorbing material index number (1 = aluminum and $13=$ air), and

THICK thickness $(\mathrm{cm})$ of the absorber. 
TARLE A.!. EYFOSURE CON: :; הNG FOR TRAMSPORT OF 5 MILLION ICSD'S FROH SUPPL!SRE TO EHNIN STORE WAREHOISES

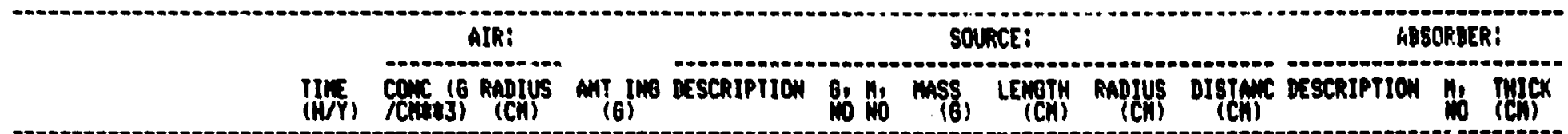

\section{TRUCK DRIVERS}

\section{grer Te roue

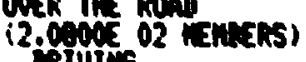 \\ ivivino}

mone Routes

(3. 3310 of of rencess) an Routts

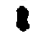

an nimess noures

(1. Fose of wencens)

iin Rovits

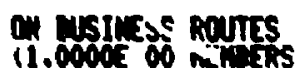

(1.0000 of initios) $\begin{array}{llll}\text { S.0 } 010.0 & 0.0 & 0.0\end{array}$

SO PMLETS

$11141.4-107,35021.5 E$ 02 1,4E O2 TRIEK PARTS

GEIMERAL PUBLIC, AVG.

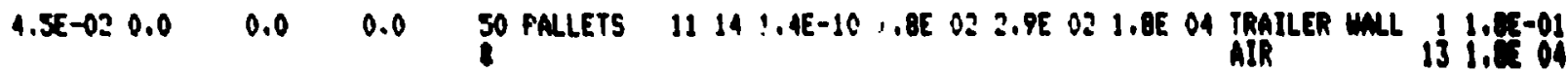

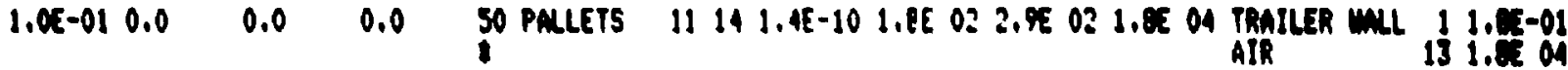
SEREMA PURIC, MAX.

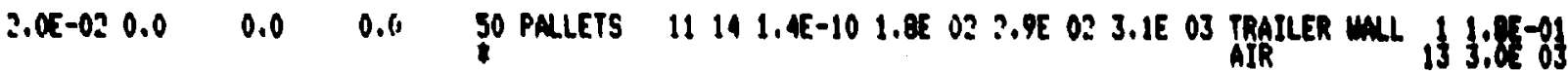


TARE A.2. EXPOSURE COMMIIIONS FON TRAMSPORT OF 5 MILLIOW ICSN'S FROA SLPPl IERS TO WOLESALE MAREROUSES

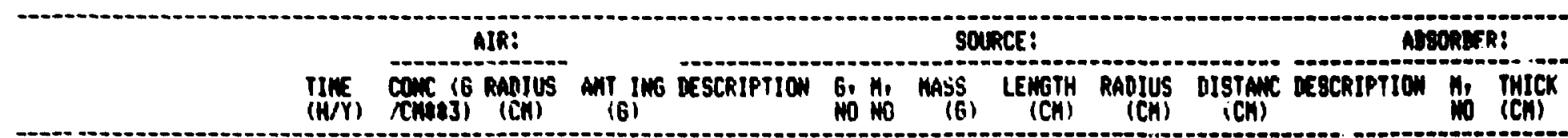

raver Dalivers

\section{Locan ploxis}

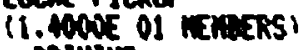
pilvins

$+$

\section{ATEIT)}

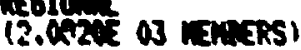
inIVIos

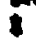

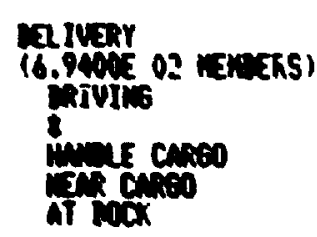

cocy ran. Mams

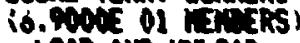
low ing ines chives

Ca6. Man. Makens (2.0021 of rithetis) low an you

in chios

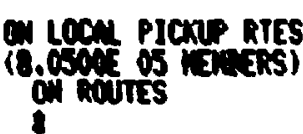

1.35020 .0

0.00 .0

$2.5 x 010.0$

0.0

0.0 1

5.05000 .0

2.0. 010.0 1.:

$\begin{array}{ll}0.0 & 0.0 \\ 0.0 & 0.0 \\ 0.0 & 0.0 \\ 0.0 & 0.0\end{array}$

10 PALLETS

1 canton

10 Pallets

11 14 $: .45-10$ 1.6E 02 1.5E O2 1.4E O2 TRUCK PABTS

12 3.0E-OL PMLETS ii i4 1.0-10 8.1E o1 1.5 029,0 ol AIR

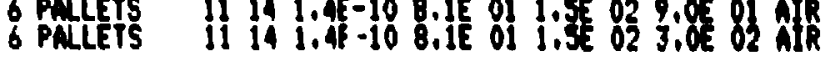

TRUCK TERW. WORKERS

$1 . \pi 010.0$ 1.02020 .0

$\begin{array}{ll}0.0 & 0.0 \\ 0.0 & 0.0\end{array}$

1 PALET

$11 \quad 142,8 E-10$ 8.1E o1 4.2E o1 $1,2 E$ O2 AIR

6 PALLETS $11141.45-108.15$ o1 $1.3502 \mathrm{~J}, 1 \mathrm{JE}$ O2 AIR

131.2502 133.1502

$8.5-010.0$

$\begin{array}{ll}0.0 & 0.0 \\ 0.0 & 0.0\end{array}$

1 PALET I1 $14: .85-108.15$ o1 4.25011 .25 O2 AIR GeVERAC PUUSC, AVG.

131.2502

4.28000 .0
$0.0 \quad 0.0$
10 $11141.4 E-101.8 E 02$ 1.4E 021.85 O4 TRUCK WALL

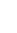


iABLE A.2. (CONTIMED)

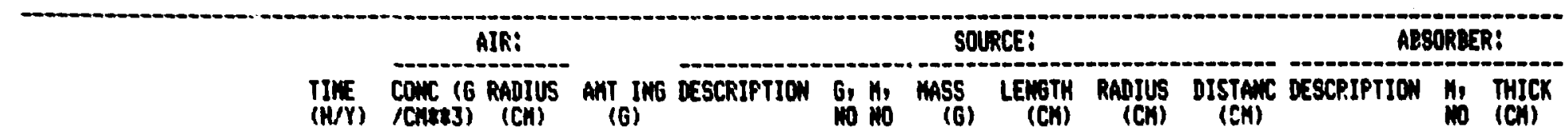

\section{CN ABIMSS Routes}

(1.9\%5e in rertiens)

o. Bot

$$
\text { i. }
$$

c) Rac Routes

(3.3310 of hentens)

ai Routes

$\checkmark$

M IEIVER NOUTES

3.99050 of rincens

ON ROUIES

$5.0 \sum-020.0$

$2.3 x-020.0$

t

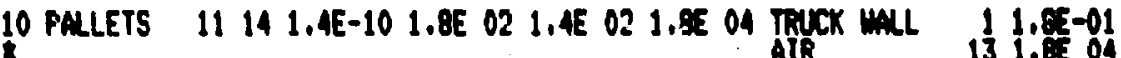

PALLTS 11 14 $1.4 E-101.8 E 021.4 E 021.8504$ TFUCK WALL $\begin{array}{rl}1 & 1.8 E-01 \\ 13 & 1.8504\end{array}$

8.3E-02 $0.0 \quad 0.0 \quad 0.0 \quad 10$ PALLTS $11141.4 E-101.8 \% 021.4 E 021.8 E$ O4 TRUCK WALL $11.8 E-01$

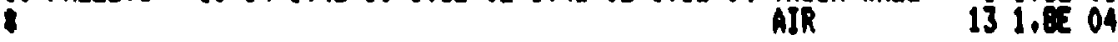
GEMERAL FUBLIC, WAX.

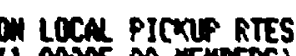

(1.00ive of ringens

in ROUIES

$8.3 E-010.0$

$0.0 \quad 0.0$

10 FALLETS $11141.4 E-101.8 E 021.4 E 023.1 E$ O3 TRUCK WALL 


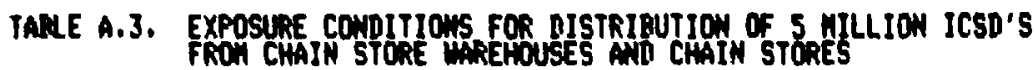

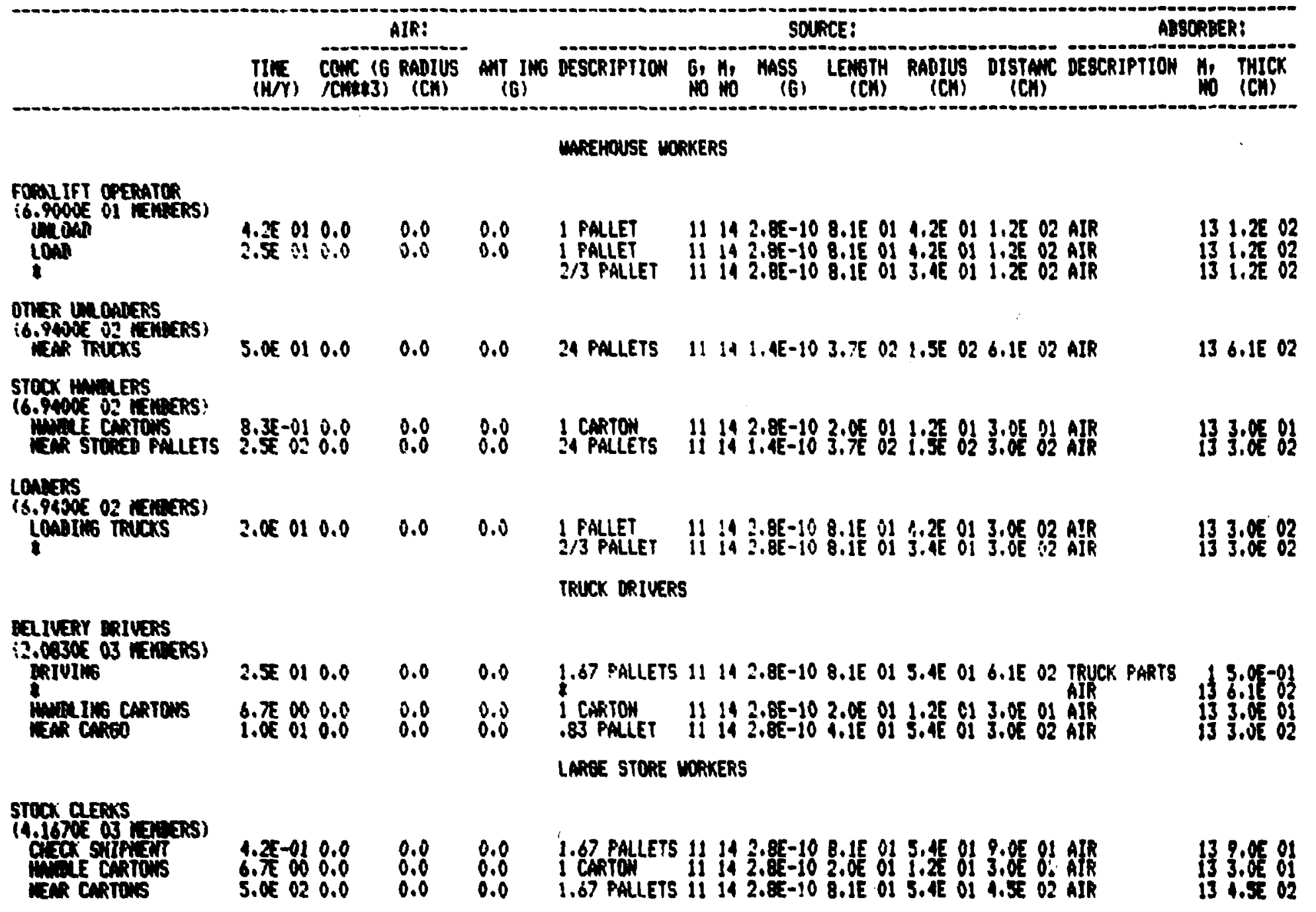


table A.3. (CONTINUED)

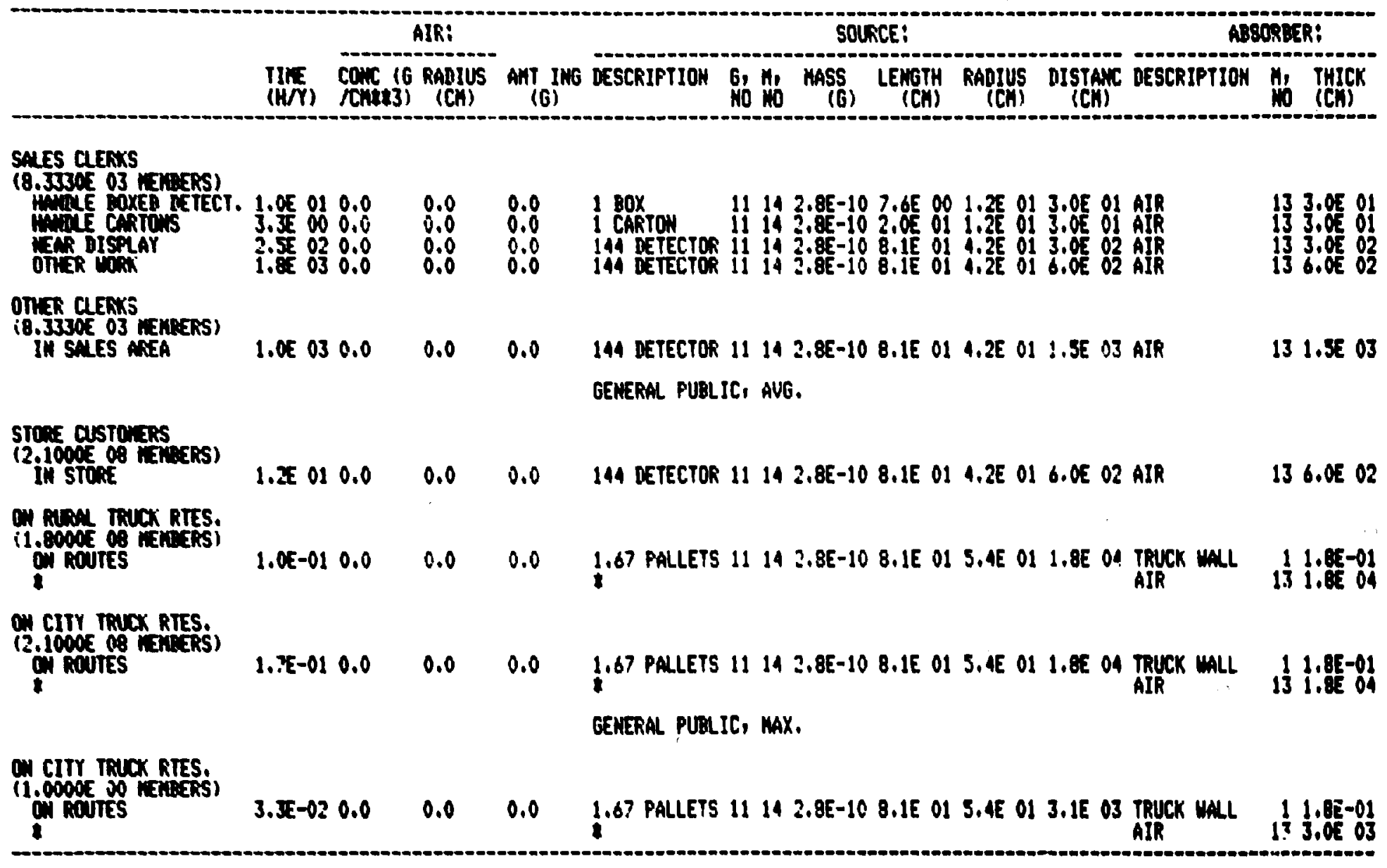




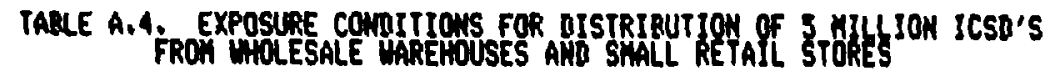

\begin{tabular}{|c|c|c|c|c|c|c|c|}
\hline & AIR: & & & RCE: & & & ABBOREER: \\
\hline $\begin{array}{l}\operatorname{Tin}_{(H / Y)} \\
(H / Y)\end{array}$ & $\begin{array}{l}\text { conc (6 RAnIUS } \\
\text { /Cnitus) (Ch) }\end{array}$ & ANT ING DESCRIPTIOH & $\begin{array}{lll}\text { G. } & \text { M, MASS } \\
\text { NO NO } & \text { (G) }\end{array}$ & $\begin{array}{l}\text { LENGTH } \\
\text { (CH) }\end{array}$ & $\begin{array}{l}\text { RAnIUS } \\
\text { (CH) }\end{array}$ & $\begin{array}{l}\text { Distanc } \\
\text { (CM) }\end{array}$ & 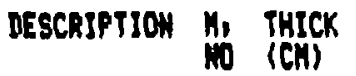 \\
\hline
\end{tabular}

WAREHOUSE WORKERS

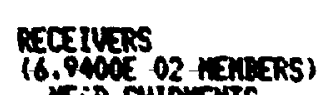

inin SNIFVichts

$5.0 E 00 \quad 0.0 \quad 0.0 \quad 0.0$ 10 PALLETS 11 14 1.4 EE-10 1.6E 02 1.5E $023.0 E$ O2 AIR

133.0502

Fome IfT OFERTTORS

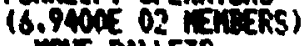

TINE PALLETS

STOCX mam EAS

13.t70 03 TEMBERS)

HWVine cartors

Fin STOEB CARTOWS

nute SHIPIINTS

2.06000 .0

2.55020 .0

$0.0-0.0$

1.55010 .0

0.0

0.0

1 PALLET

11 14 2.8E-10 8.1E O1 4.2E O1 1.2E O2 AIR

$131.2 E 02$

lowiss

(2. CBave 03 VIneTS)

mate cantors

6.7E 00

$0.0 \quad 0.0$ I CARTOM

$0.0 \quad 0.0 \quad 6$ PALLETS

$11142.8 E-102.0 E$ O1 $1.2 E$ O1 3.05 O1 AIR

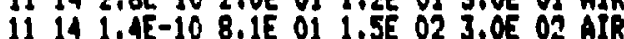

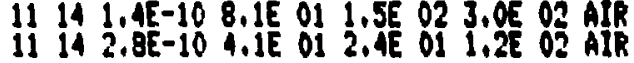

133.05 O1

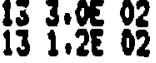

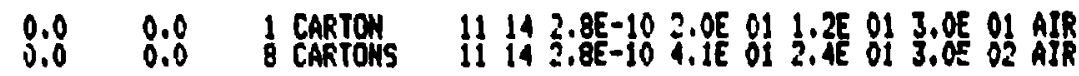

133.0501

TRUCK DRJUERS

\section{warvar mivers}

(1. Oilo of rincas)

MRIVISo

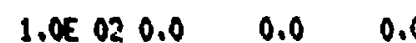

imoanins cartons

istion silpint

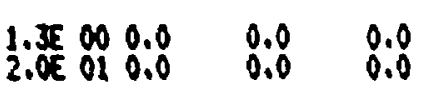

8 CARTOHS

* cantars

1 CABTOU $11142.85-102.05$ o1 1.25 or 3.05 of Alt

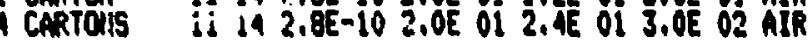

SHALL STORE WORKERS

\section{STOCX CLEAKS}

(2. conot of rentiens)

imaxe cantons

6.7E-01 $0.0 \quad 0.0 \quad 0.0$ I CARTON $11142.8 E-102.0 E 011.2 E 013.0 E$ O1 AIR

133.0601 
TARLE A.4, (CONTINUES)

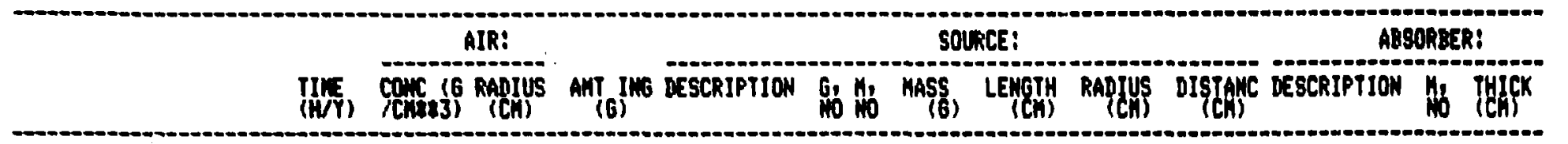

SNES atous

14.1640 OS (ENACES)

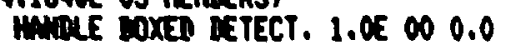

TEAR DISPLAY I.0E 030.0

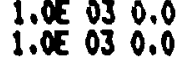

0.9

0.0
0.0

0.0

OTKR IOAK

1 DETECTOR 11 14 $2.8 E-107.6 E$ O0 1.22013 .00 O1 AIR 12 DETECTORS 11 14 $2.8 E-102.08$ ol $2.4 E$ ol $3.0 E$ Oa AlR

133.0601 GENERAL FUBLIC, AUG.

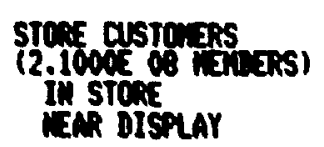

$4.0 E 010.0$ l.

$0.0 \quad 0.0$

12 EETECTORS I1 $142.8 E-103.0 E$ O1 $2.4 E$ O1 6.0E O2 ALR

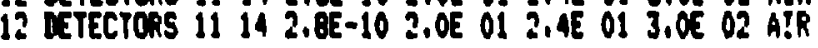

136.0502

ON mucx ROUTES

(2.100) of Kencens)

ON RUTES

$3.35-010.0$

$0.0 \quad 0.0$

8 CARTONS

$11142.8 E-104.1 E 012.4 E 011.8 E$ O4 TRUCK MALL

geVERA PUALIC, max,

Oin $\max$ goures

ON ROUTES $6 . \pi E-020.0 \quad 0.0 \quad 0.0 \quad 8$ CARTOWS $11142.8 E-10$ 4.1E $012.4 E 013.1 E$ 03 TRUPX WML

$1 \frac{1}{1} .85-01$ 133.0203 


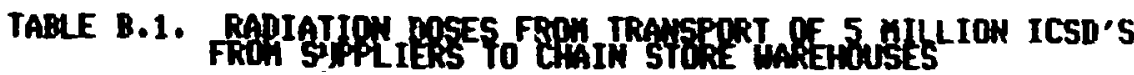

BOSEE TO MOLE BOOY

IMIVIDUAL BOSE EQUIVALEKT, SU

EXTERWA INTERANA TOTAL

POPULATIOM DASE

EQUIUALENT.

PERSON-SU

TRUCK DAIVERS

OUER THE ROAD

(2.080E 02 HEMBERS)

DRIVING

$3.33 E-08 \quad 0.0$

$3.33 E-08$

$6.92 E-06$

DOSE TO DUER THE ROAD

3. $33 E-08$

3. 33E- 08

$6.92 E-06$

SUMARY OF DOSES FOR TRUCK DRIVERS

: LOMEST 3.33E-08

HIGHEST 3.33E-08

TOTAL

$6.92 E-06$

GENERAL PUBAIC, AUG.

ON RURAL ROUTES

(3.331E O6 MEKBERS)

ON R.OUTES

$7.36 E-15 \quad 0.0$

$0.0 \quad 7.36 \mathrm{E}-15$

2.45E-08

DOSE TO ON RURAL ROUTES

7.3CE-15

0.0

$7.36 \mathrm{E}-\mathrm{i5}$

2. $45 E-08$

ON BUSINESS ROUTES

(1.995E O7 MEHBERS)

DN ROUTES

$1.62 \mathrm{E}-14 \quad 0.0$

$1.62 E-14$

$3.23 E-07$

LOSE TO ON BUSINESS ROUTES

$\overline{1.62 \mathrm{E}-14} \quad \overline{0.0}$

1. E2E-14

3.23E-07

SUMMARY OF DOSES FOR GENER:AL FUBLIC, AUG.: LOUEST $7.36 E-15$

HISHEST 1.32E-14

TOTAL

$3.47 E-07$

GENERAL PUELIC, HAX.

ON BUSINESS ROUTES

( $1.000 E$ 0O MEHBERS

ON ROUTES

$2.03 E-13 \quad 0.0$

$2.03 E-13$

0.0

DOSE TO ON BUSINESS ROUTES

$2.035-13-0.0$

$2.03 E-13$

0.0

SUMHARY OF DOSES FOR GENERAL FUBLIC, MAX.: LOHEST $2.03 E-13$

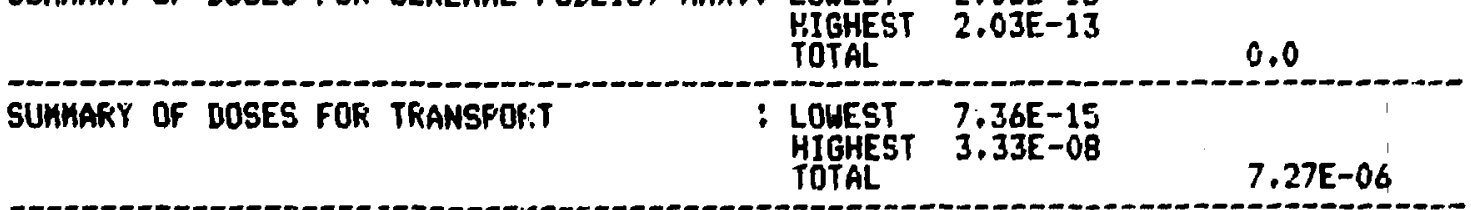




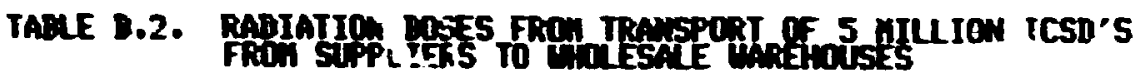

DOSES II MOLE EODY

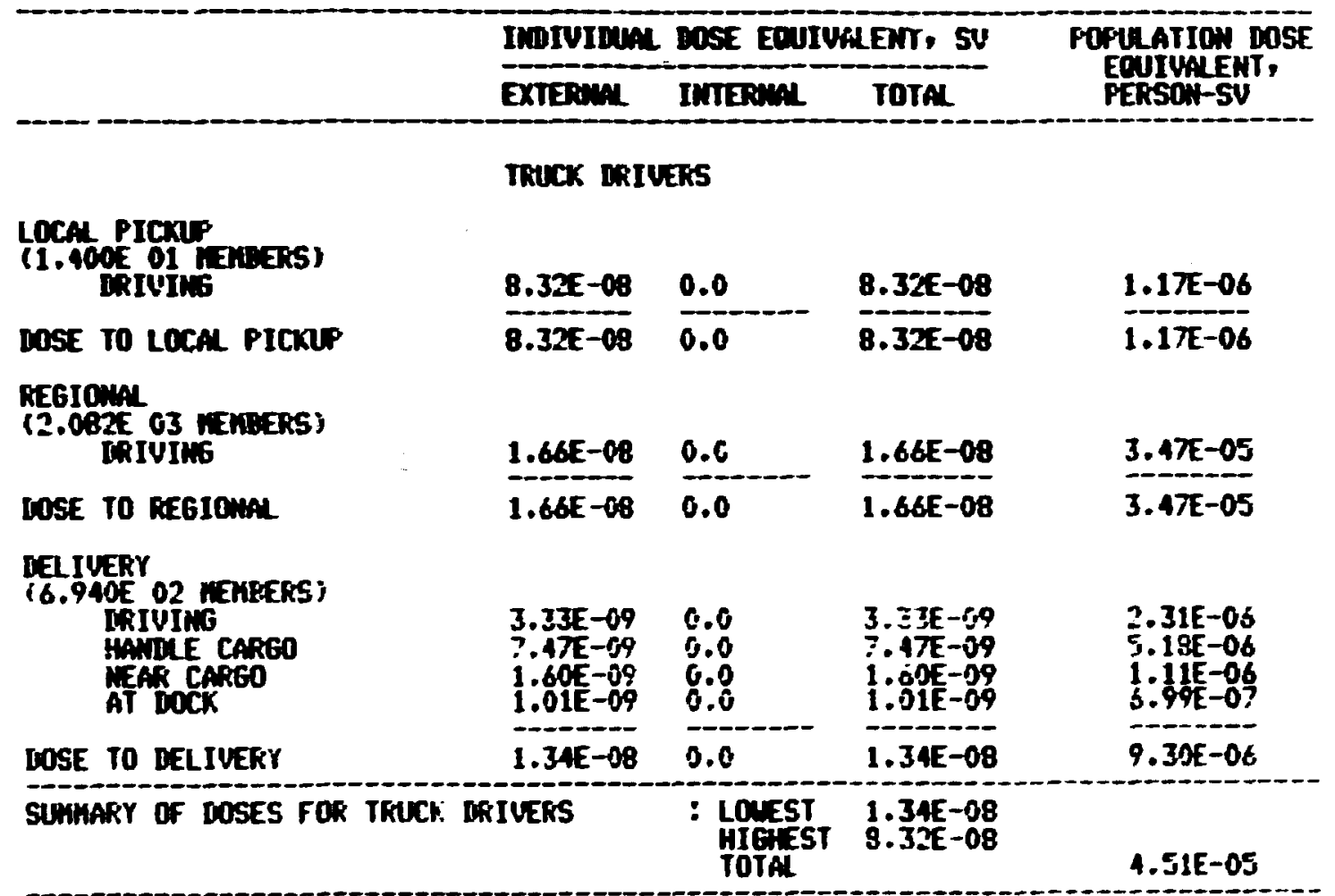

TRUCK TERH. WOKKERS

LOCAL TERH. WOCKERS

(6.900E OI VERBERS)

LOAD ANI UMDDAD

inear cargo

$5.12 E-09$

2.61E-08

0.0

$5.12 E-09$

2. $.1 E-08$

3.53E-07

3.12E-08

0.0

$0.0 \quad 3.12 E-.08 \quad 2.15 E-06$

$1.806-06$

REG. TERK, MORKERS

(2.082E 93 MEMEERS)

IJAI AND UTLOAI

neAR CARGo

\section{$2.56 \mathrm{E}-10$}

2.61E-09

$0.0 \quad 2.56 E-10$

$3.61 E-09$

5. 32E-07

2.87E-09

-

$2.87 E-59$

$5.43 \mathrm{E}-06$

DOSE TO REG. TERK. WORKERS

0.0

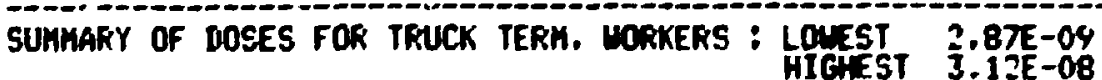


TABAE B.2. (COMIMED)

\begin{tabular}{|c|c|c|c|c|}
\hline & \multicolumn{3}{|c|}{ IMDIVIDUAL DOSE EQUIVALENT, SU } & \multirow{2}{*}{$\begin{array}{l}\text { POPLLATION DOSE } \\
\text { EDUIULAET. } \\
\text { PERSO-SV }\end{array}$} \\
\hline & EXTERTAL & INTERAAL & TOTAL & \\
\hline & \multicolumn{3}{|c|}{ GEMERAL PUELIC, AVG. } & \\
\hline $\begin{array}{c}\text { CN LOCAL PICKUP RTES } \\
\text { (8.05OE O5 HERBERSS } \\
\text { ON ROUTES }\end{array}$ & $1.52\{-13$ & 0.0 & $1.52 E-13$ & $1.22 \pm-07$ \\
\hline DOSE TO ON LOCAL PICKUF RTES & $1.52 E-13$ & 0.0 & $1.52 E-13$ & $1.22 E-07$ \\
\hline $\begin{array}{c}\text { ON GUSINESS ROUTES } \\
\text { (1.995E OQ HENLERS) } \\
\text { ON ROUTES }\end{array}$ & $1.81 E-15$ & 0.0 & $1.81 E-15$ & $3.61 E-07$ \\
\hline DOSE TO ON BUSIMESS ROUTES & $1.81 E-15$ & 0.0 & $1.81 E-15$ & $3.61 E-07$ \\
\hline $\begin{array}{l}\text { ON RURAL ROUTES } \\
\text { (3.331E OS RIEMEERS) } \\
\text { ON ROUTES }\end{array}$ & 8.32E-16 & 0.0 & 8.32E-1s & $2.77 E-09$ \\
\hline DOSE IJ ON FURAL RCUTES & 8.32E-1s & 0.0 & $8.32 E-16$ & $2.77 E-09$ \\
\hline $\begin{array}{c}\text { ON DELIUERY ROUTES } \\
\text { (3.990E 07 NEHIEERS }) \\
\text { ON ROUTES }\end{array}$ & $3.00 E-15$ & 0.0 & $3.00 E-15$ & $1.20 E-07$ \\
\hline DOSE TO ON IELLIUERY ROUTES & $3.00 E-15$ & 0.0 & $3.00 E-15$ & $1.20 E-07$ \\
\hline SUMMARY OF UOSES FDR GENERAL & \multicolumn{2}{|c|}{$\begin{aligned} & \text { FUELIC, AUG.: } \text { LDWEST } \\
& \text { HOTGEST } \\
& \text { TOTAL }\end{aligned}$} & $\begin{array}{l}8.32 \mathrm{E}-16 \\
1.52 \mathrm{E}-13\end{array}$ & $6.05 E-07$ \\
\hline \multicolumn{5}{|c|}{ GENERAL PUBLIC, MAX. } \\
\hline $\begin{array}{c}\text { ON LOCAL PICKUF RTES } \\
\text { (1.000E OO MEMEERS } \\
\text { ON ROUTES }\end{array}$ & $1.90 E-12$ & 0.0 & $1.90 E-12$ & 0.0 \\
\hline DOSE TO ON LOCAL PICKUP RTES & $1.90 E-12$ & 0.0 & $1.90 E-12$ & 0.0 \\
\hline SUKHARY OF JOSES FOR GENERAL & FUBLIC, MA & $\therefore \begin{array}{l}\text { LOUEST } \\
\text { HIGHEST } \\
\text { TOTAL }\end{array}$ & $\begin{array}{l}1.90 \mathrm{E}-12 \\
1.90 \mathrm{E}-12\end{array}$ & 0.0 \\
\hline SUMKAFY OF DOSES FOR TRANSPOF & & $\begin{array}{l}\text { : LOUEST } \\
\text { HIGHEST } \\
\text { TOTAL }\end{array}$ & $\begin{array}{l}8.32 E-16 \\
8.32 E-08\end{array}$ & $5.39 E-05$ \\
\hline
\end{tabular}




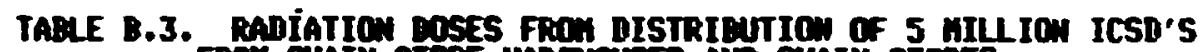
FRoH chaIn stoie undentrses and chaIn stodes

DOSES TO GOLE Bow

\begin{tabular}{|c|c|c|c|c|}
\hline & \multicolumn{3}{|c|}{ InDIUIDUAL DOSE EOUIUAKENT, SU } & \multirow{2}{*}{ 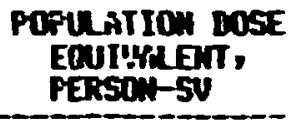 } \\
\hline & EXTERatial & IUTERHAL & TOTAL & \\
\hline & \multicolumn{3}{|c|}{ UAMEMUUSE MoRKERS } & \\
\hline 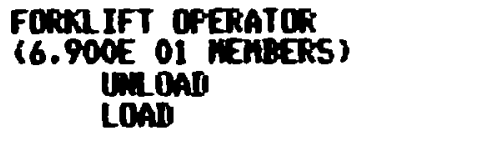 & $\begin{array}{l}1.25 E-08 \\
1.2 \pi \mathrm{E}-08 \\
\end{array}$ & $\begin{array}{l}0.0 \\
0.0 \\
\end{array}$ & $\begin{array}{l}1.25 E-08 \\
1.2 \pi E-09\end{array}$ & $\begin{array}{l}8.66 E-07 \\
8.75 \mathrm{~K}-07\end{array}$ \\
\hline DOSE TO FOAXLIFT OPERATOR & $2.52 E-08$ & 0.0 & $2.52 E-08$ & $1.74 E-06$ \\
\hline 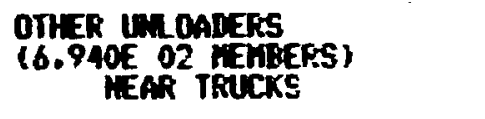 & $3.60 E-09$ & 0.0 & $3.60 E-09$ & $2.5 \mathrm{JE} \rightarrow \mathrm{OS}$ \\
\hline IOSE TO OTHER UMMOAIEKS & $3.60 E-69$ & 0.0 & $3.60 E-09$ & $2.50 E-06$ \\
\hline $\begin{array}{l}\text { STOCK HAWLERS } \\
\text { (6.940E O? REMEEFS) } \\
\text { HWWL CAFTOWS } \\
\text { WEAR STORED FALLETS }\end{array}$ & $\begin{array}{l}3.1 \mathrm{E}-10 \\
3.71 \mathrm{E}-\mathrm{j}\end{array}$ & $\begin{array}{l}0.0 \\
0.0\end{array}$ & $\begin{array}{l}3.13 E-10 \\
6.71 E-08\end{array}$ & $\begin{array}{r}2.17 E-07 \\
4.56 E-05 \\
-\end{array}$ \\
\hline DOSE TO STOCK HANDLERS & $6.74 E-08$ & 0.0 & $6.74 E-6 E$ & $4.68 \mathrm{EE}-05$ \\
\hline $\begin{array}{l}\text { LOADEES } \\
\text { (6.94DE O2 MENGERS } \\
\text { LOADING IKUCKS }\end{array}$ & $1.73 E-09$ & 0.0 & $1.23 E-09$ & $1.2 \mathrm{GE}-0 t$ \\
\hline DOSE TO LOAIEERS & $1.73 E-59$ & 0.0 & $1.73 E-09$ & $1.20 E-06$ \\
\hline SUMMARY OF IUSES FOR UAKEH & IOKKERS & $\begin{array}{l}: \text { LOMEST } \\
\text { HIETEST } \\
\text { TOTAL }\end{array}$ & $\begin{array}{l}1.73 E-09 \\
3.74 E-68\end{array}$ & $5.22 E-05$ \\
\hline
\end{tabular}

TRUCK DRIUERS

TELIUERY WFIVERS

!2.083F O3 MEHEERS )

IRIVING

HANILING CAKTONS

NEAR CARGO

$4.36 \varepsilon-10$
$2.50 E-09$
$8.55 z-10$

0.0

0.0

3.0

$4.36 E-10$

$2.50 E-09$

a. 55t-10

$3.79=-09$

-

3.79E-09

$9.08 E-07$

5.21E-00

$1.78 E-06$

DOSE TO DELIVERY DRIVERS

3.79E-09 0.0

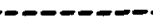

SUMmaFiY OF IOSES FOF TRUCK DRIVERS

: LOMEST 3.79E-09

HIGHEST ?.79E-09

TOTAL

$7.89 E-06$

LARGE STORE WORKERS

ETOC: CLEFYS

4. IETE DI MEMBERS)

GMERR. SHIPMENT

HANULE CARTONS

MEAF CARTONS

UJÉ $T r_{i}$ SPOCK CLERKS

\begin{tabular}{lll}
$3.21 E-10$ & 0.0 & $3.21 E-10$ \\
$2.511 E-09$ & 0.0 & $2.01 E-09$ \\
$1.91 E-08$ & 0.0 & $1.91 E-08$ \\
\hline $2.19 E-08$ & 0.0 & $2.19 E-08$
\end{tabular}

1.34E-06

$1.04 E-05$

$7.96 E-05$

9.14E-65

$9.14 E-65$ 
TADEE B.3. (CONTINated)

\begin{tabular}{|c|c|c|c|c|}
\hline & Inorvitua & CASE ENUI & ALET, su & Poprearion cose \\
\hline & EXTEDAuA & IUTERan & TOTa & PER \\
\hline 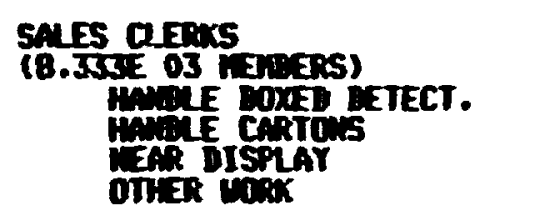 & $\begin{array}{l}3.37 E-\infty 9 \\
1.25 E-09 \\
1.29 E-06 \\
2.25 E-\infty 6\end{array}$ & $\begin{array}{l}0.0 \\
0.0 \\
0.0 \\
0.0\end{array}$ & $\begin{array}{l}3.37 E-09 \\
1.25 E-09 \\
1.2 \% E-08 \\
2.25 k-00\end{array}$ & $\begin{array}{l}2.81 E-05 \\
1.0 E-05 \\
1.060-04 \\
1.86 E-04\end{array}$ \\
\hline DOSE TO SALES CaERKS & $4.01 E-08$ & 0.0 & $9.01 E-08$ & $\overline{3.34 E-04}$ \\
\hline 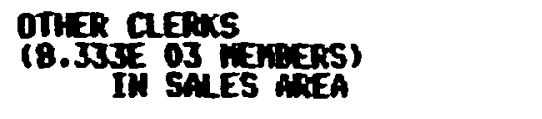 & $1.98 E-09$ & 0.0 & $1.98 E-09$ & $1.65 E-05$ \\
\hline DOSE TO OTHER CLERKS & $1.98 E-09$ & 0.0 & $1.98 E-09$ & $1.65 E-05$ \\
\hline SUDWAFY OF BOSES FOR LAREE SI & TORE MOEKERS & $\begin{array}{l}\text { L LQEST } \\
\text { HIGHEST } \\
\text { TOTAL }\end{array}$ & $\begin{array}{l}1.98 E-09 \\
4.01 E-68\end{array}$ & $4.42 E-04$ \\
\hline & GEMERAL PUI & MaIC, ANG. & & \\
\hline 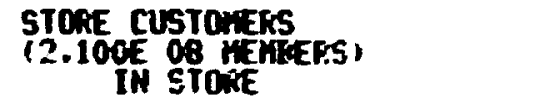 & $1.5+\bar{z}-10$ & 0.0 & $1.54 E-1.3$ & $3.24 E-62$ \\
\hline DOSE TO STOKE CUSTOHERS & $1.54 E-10$ & 0.0 & $1.54 E-10$ & $3.24 E-02$ \\
\hline $\begin{array}{l}\text { OW RURAL TRUCK RTES. } \\
\text { (1.800E OE HEMEERS) } \\
\text { OW ROUTES }\end{array}$ & 1.12E-15 & 0.0 & $1.12 E-15$ & $2.52 E-07$ \\
\hline DOSE TO ON RUERAL TKUCY. RTES. & $1.12 E-15$ & 0.0 & $1.12 E-15$ & $2.02 E-07$ \\
\hline 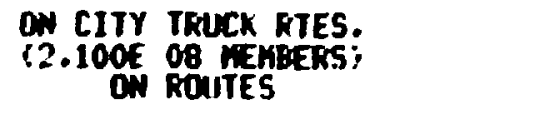 & $1.91 E-15$ & 0.0 & $1.91 E-15$ & $4.01 E-07$ \\
\hline DOSE TO ON CITY TRUCK RTES. & $1.91 E-15$ & 0.0 & $1.91 E-15$ & $4.01 E-07$ \\
\hline SUMAFAY OF DOSES FOR GEMERAI & ELIC, & $\therefore \begin{array}{l}\text { LOWEST } \\
\text { HIGHEST } \\
\text { IOTAR }\end{array}$ & $\begin{array}{l}1.13 E-15 \\
1.54 E-10\end{array}$ & $3.24 E-02$ \\
\hline
\end{tabular}

GenERAL PUELIC, max.

ON CIIP TRUCK RTES.

(1.00OE OO MEMEERS;

ON ROUTES

IOSE TO ON CITY TRUCK RTES.

$\frac{2.34 E-14}{2.34 E-14} \quad 0.0$

2.34E-14

$3.345-14$

$0: 0$

SUMmARY Of DOSES FOR GEMERAL PUELIC, HAX,: LOUEST $2.34 E-14$

HIGHEST $2.34 E-14$

TOTAL

0.0

SUWMARY OF DOSES FOR OISTRIEUTIOW

: LOLSTT 1.12E-15

HIGHEST $6.74 E-08$

Torat 


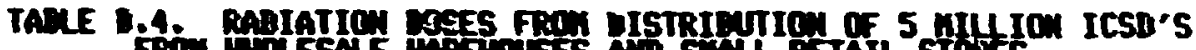

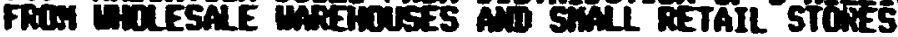

DOSES To male bobY

\begin{tabular}{|c|c|c|c|c|}
\hline \multirow{2}{*}{ - } & \multicolumn{3}{|c|}{ IWIUTEUM DOSE EOUIUALET, SV } & \multirow{2}{*}{$\begin{array}{l}\text { POPULATIOW DOSE } \\
\text { EOUIVALERT, } \\
\text { PERSON-SV }\end{array}$} \\
\hline & EXTERMAL & IMTERavil & TOTAL & \\
\hline ¿ & \multicolumn{3}{|c|}{ MAREMDUSE UORKERS } & \\
\hline 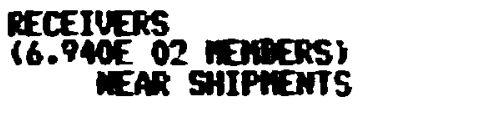 & $1.34 E-09$ & 0.0 & $1.34 E-09$ & $9.32 \varepsilon-07$ \\
\hline DOSE TO RECEIUERS & $1.34 E-09$ & 0.0 & $1.34 E-09$ & $9.32 E-07$ \\
\hline 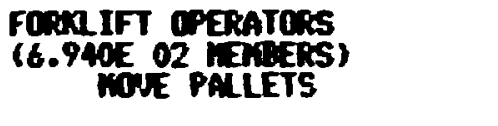 & $1.25 E-09$ & 0.0 & $1.25 E-09$ & 8.71E-0: \\
\hline IOSE TO FOAKLIFT OFERATONS & $1.25 E-09$ & 0.0 & $1.25 E-09$ & $8.71 E-07$ \\
\hline 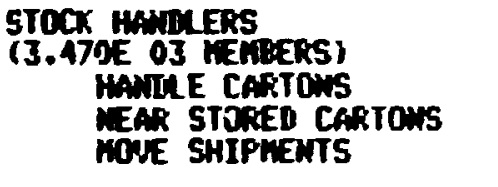 & $\begin{array}{l}7.51 E-10 \\
6.71 E-08 \\
1.59 E-69\end{array}$ & $\begin{array}{l}0.0 \\
0.0 \\
0.0\end{array}$ & $\begin{array}{l}7.51 E-10 \\
6.711 E-08 \\
1.59 E-69\end{array}$ & $\begin{array}{l}2.50 E-06 \\
2.33 E-04 \\
5.52 E-06\end{array}$ \\
\hline DOSE TO STOCK HANGEERS & $6.95 E-08$ & 0.0 & $6.95 E-605$ & $2.41 E-04$ \\
\hline 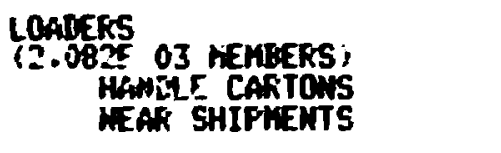 & $\begin{array}{l}2.50 E-29 \\
1.74 E-09\end{array}$ & $\begin{array}{l}0.0 \\
0.0\end{array}$ & $\begin{array}{l}2.50 E-09 \\
\vdots .74 E-09\end{array}$ & $\begin{array}{l}5.21 E-06 \\
3.62 E-06\end{array}$ \\
\hline DOSE TO LOAIEKS & $4.24 E-09$ & 0.0 & $4.24 E-90$ & $8.23 E-06$ \\
\hline SUMWAFi OF DOSES FOR WAREY & WokkERS & $\begin{array}{l}: \text { LOWEST } \\
\text { HIGHEST } \\
\text { TOTAL }\end{array}$ & $\begin{array}{l}1.25 E-09 \\
6.95 E-08\end{array}$ & $2.52 E-04$ \\
\hline
\end{tabular}

TRUCK ORIUERS

GEL IUERY ORIVERS

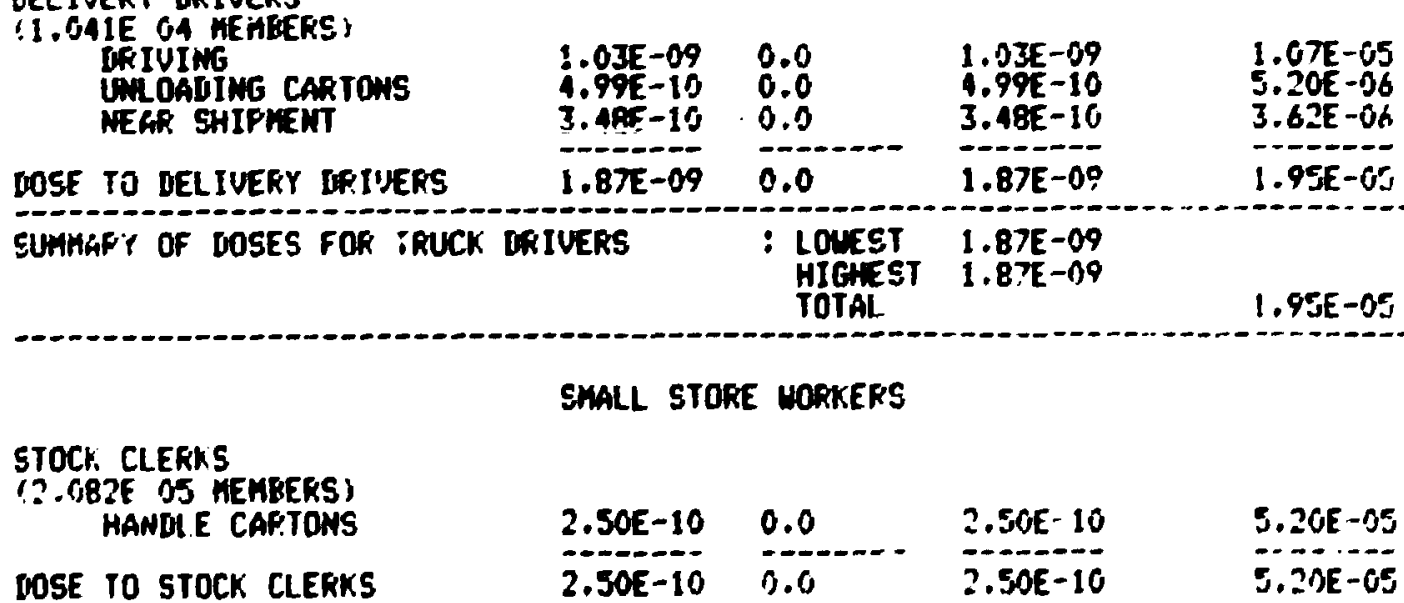


TALEE B.4. (CONTIMED)

\begin{tabular}{|c|c|c|c|c|}
\hline & \multicolumn{3}{|c|}{ IMBIVIDUAL DOSE EOUIVALENT, SV } & \multirow{2}{*}{ 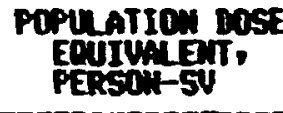 } \\
\hline & EXTERaAl & INTERAML & Total & \\
\hline \multicolumn{5}{|l|}{ 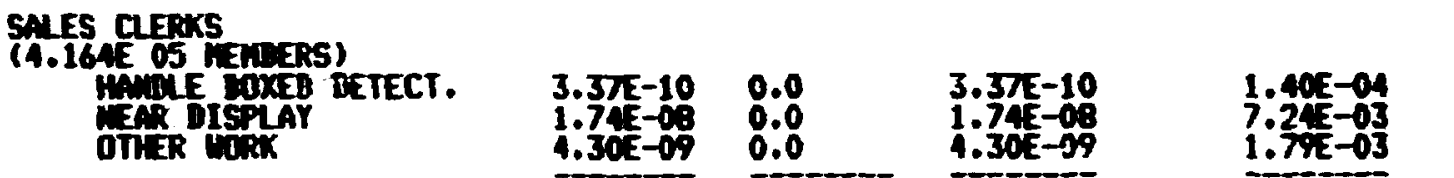 } \\
\hline DOSE TO SALS CLEKKS & $2.20 E-08$ & 0.0 & $2.20 E-08$ & $9.17 E-03$ \\
\hline \multicolumn{3}{|c|}{ 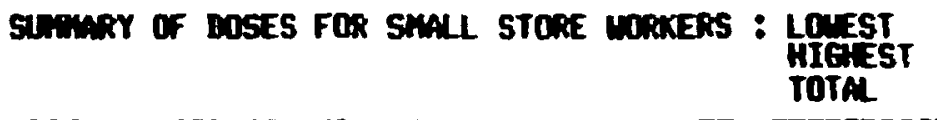 } & $\begin{array}{l}2.50 E-10 \\
2.20 \mathrm{E}-08\end{array}$ & $9.22 E-03$ \\
\hline \multicolumn{5}{|c|}{ GENERA PURAIC, AVG. } \\
\hline $\begin{array}{l}\text { STORE CUSTOYERS } \\
\text { (2.10OE OQ HERBERS } \\
\text { IV STORE } \\
\text { WEAR DISFLAY }\end{array}$ & $\begin{array}{l}1.72 E-10 \\
1.74 E-10\end{array}$ & $\begin{array}{l}0.0 \\
0.0\end{array}$ & $\begin{array}{l}1.72 E-10 \\
1.74 E-10\end{array}$ & $\begin{array}{l}3.61 E-02 \\
3.65 E-02 \\
\end{array}$ \\
\hline \multirow{2}{*}{$\begin{array}{l}\text { IOSE TO STORE CUSTONERS } \\
\text { ON TKUCK ROUTES } \\
\text { (2.100E OB WENIEES) } \\
\text { DN ROUTES }\end{array}$} & $3.46 E-10$ & 0.0 & $3.465-10$ & $7.26 E-02$ \\
\hline & $7.47 \mathrm{E}-16$ & 0.0 & $7.47 \pm-16$ & $1.5 ; E-07$ \\
\hline LOSE TO ON TKUCK ROUTES & $7.47 E-16$ & 0.0 & $7.47 \mathrm{E}-16$ & \multirow[b]{2}{*}{$7.26 E-02$} \\
\hline \multicolumn{4}{|c|}{ SUWWAKY OF IMOSES FOF GENERAL PUBLIC, AUG.: LOUEST $\begin{array}{c}\text { HIGHEST } \\
\text { TITAL }\end{array}$} & \\
\hline \multicolumn{5}{|c|}{ GENERAL PUBLIC, MAK. } \\
\hline $\begin{array}{l}\text { ON TRUCK ROUTES } \\
\text { (1.000E OQ MEMBERS) } \\
\text { ON ROUTES }\end{array}$ & $9.46 E-15$ & 0.0 & $9,46 E-15$ & 0.0 \\
\hline DOSE TO ON TRUCK ROUTES & $9.46 E-15$ & 0.0 & $\therefore .46 E-15$ & \multirow[b]{2}{*}{0.0} \\
\hline \multicolumn{4}{|c|}{$\begin{array}{l}\text { SUMAGKY OF DOSES FOK GENEKAL PUBLIC, MAX.: LOUEST } \\
\text { HIGHEST } \\
\text { TOTAL }\end{array}$} & \\
\hline \multicolumn{4}{|c|}{$\begin{array}{l}\text { SUMHASY OF DOSES FOR IISTKIBUTION } \\
\text { HOLEST } \\
\text { IOTALT }\end{array}$} & $8.21 E-02$ \\
\hline
\end{tabular}

